\title{
Application of a modeling approach to designate soil and soil organic carbon loss to wind erosion on long-term monitoring sites (BDF) in Northern Germany
}

\author{
Rainer Nerger ${ }^{1}$, Roger Funk ${ }^{2}$, Eckhard Cordsen ${ }^{3}$ and Nicola Fohrer ${ }^{1}$
}

1 Department of Hydrology and Water Resources Management; University of Kiel;

Olshausenstraße 40, 24098 Kiel, Germany

${ }^{2}$ Institute of Soil Landscape Research, Leibniz Centre for Agricultural Landscape Research

(ZALF); Eberswalder Straße 84; 15374 Müncheberg; Germany

3 Department Geology and Soil, Soil Conservation; State Agency of Agriculture, Environment and

Rural Areas of the Federal State Schleswig-Holstein (LLUR), Hamburger Chaussee 25, 24220

Flintbek, Germany

\section{Corresponding Author:}

Mr. Rainer NERGER ${ }^{1}$

Email: rnerger@hydrology.uni-kiel.de

\section{Corresponding Author's affiliation address:}

Department of Hydrology and Water Resources Management; University of Kiel

Olshausenstraße 40

24098 Kiel

Germany

\footnotetext{
1 Corresponding Author's present address:

Nagelshof 18

22559 Hamburg

Germany
}

(C) 2016. This manuscript version is made available under the Elsevier user license 


\section{Application of a modeling approach to designate soil and soil organic carbon loss to} wind erosion on long-term monitoring sites (BDF) in Northern Germany

\section{Abstract}

Soil organic carbon (SOC) loss is a serious problem in maize monoculture areas of Northern Germany. Sites of the soil monitoring network (SMN) "Boden-Dauerbeobachtung" show long-term soil and SOC losses, which cannot be explained neither by conventional SOC balances nor by other non-Aeolian causes. The main objective was to determine whether these losses can be explained by wind erosion shown on the use of a processbased model.

In the long-term context of 10 years wind erosion was not measured directly but often observed. A suitable estimation approach was linking high-quality soil/farming monitoring and wind speed data with modeling results. The model SWEEP, validated for German sandy soils, was used. Two similar local SMN study sites were compared. Site A was characterized by high SOC loss and often affected by wind erosion; the reference site $B$ was not.

At site A soil mass and SOC stock decreased by 49.4 and $2.44 \mathrm{~kg} \mathrm{~m}^{-2}$ from 1999 to 2009. Using SWEEP, a total soil loss of $48.9 \mathrm{~kg} \mathrm{~m}^{-2}$ resulted for 16 erosion events (max. single event $12.6 \mathrm{~kg} \mathrm{~m}^{-2}$ ). A share of $78 \%$ was transported by suspension with a SOC enrichment ratio (ER) of 2.96 (saltation ER 0.98), comparable to the literature. At the reference site measured and modeled topsoil losses were minimal.

The good agreement between measurements and modeling results suggested that wind erosion caused significant long-term soil and SOC losses. The approach uses results of prior studies and is applicable to similar well-studied sites without other noteworthy SOC losses.

Keywords: long-term soil monitoring; BDF; SOC loss; wind erosion modeling; SWEEP; Northern Germany 


\section{Introduction}

\subsection{Background and research gap}

Soil organic carbon $\left(\mathrm{SOC}^{1}\right)$ loss of arable soils is one of the main impacts of land degradation, triggered by a variety of physical and chemical factors, but finally caused by inappropriate land use (FAO \& ITPS, 2015; Lal, 2014, 2003; Louwagie et al., 2009; Verheijen et al., 2009). Wind erosion can be a reason of gradual soil degradation, but the processes themselves are difficult to recognize or measure in the field.

In the flat sandy lowlands of Schleswig-Holstein in Northern Germany wind erosion is also a common process (Hassenpflug, 1998; Duttmann and Bach, 2006; Duttmann et al., 2011). SOC-rich sandy soils were developed on formerly heathland by Plaggen fertilization of livestock residues from stables (Giani et al., 2014; Blume, 2004; Springob et al., 2001; Springob and Kirchmann, 2002), characterized as Plaggic Anthrosols (IUSS, 2006). Used as arable land these sites are highly susceptible to wind erosion (Riksen and Graaff, 2001). Quantitative and qualitative effects of wind erosion on these soils were investigated sporadically only in a few studies. Direct field measurements of wind erosion are sparsely available for the region (Funk et al., 2004; Goossens and Gross, 2002; Goossens, 2004), even less is known about the amount of SOC loss by wind erosion (Bach, 2008) and nothing about the long-term losses over decades. For the latter, the most plausible reasons are the high technical and organizational efforts to measure wind erosion over long periods.

However, some soils exhibit decreased soil mass and SOC stock in the topsoil, i.e. the Ap horizon (LLUR, 2010; Ad-Hoc-AG Boden, 2005). Several authors recommend to consider these changes for estimating erosion losses in combination with modeling approaches (e.g. Post et al., 2001; Kibblewhite et al., 2012; Lal, 2005). Kibblewhite et al. (2012) state that soil erosion reduces topsoil depth, soil mass and SOC in the Ap horizon and suggests the use of long-term soil monitoring data to identify these changes. Even without direct measurements of wind erosion, the long-term monitoring of these soil parameters enables the assessment of the changes over decades (Post et al., 2001). Chappell \& Viscarra Rossel (2013) and Chappell \& Baldock (2016) describe the importance

\footnotetext{
${ }^{1}$ Abbreviation list:

BDF Boden-Dauerbeobachtungsfläche (long-term soil monitoring site)

DIN German Industry Standard (Deutsches Institut für Normung)

DWD German Meteorological Service (Deutscher Wetterdienst)

ER Enrichment ratio

GMD Geometric mean diameter

GSD Geometric standard deviation

LAI Leaf area index

LLUR State Agency

SAl Stem area index

SMN Soil monitoring network

SOC Soil organic carbon

SWEEP Single-event Wind Erosion Evaluation Program

TEAM Texas Tech Erosion Analysis Model

WEPS Wind Erosion Prediction System
} 
of soil monitoring, sampling design on the detection of wind erosion and the absence of aeolian SOC losses from management-focused SOC balances. To conclude all these studies; reproducing measured SOC changes with a process-based wind erosion model may help to identify the contribution of wind erosion on SOC losses, which is not included in SOC balances so far. Using this approach, it is necessary to exclude other possible sources of SOC loss. Dust emission by tillage, was considered negligible for typical soil moisture conditions in the periods of wind erosion (Öttl and Funk, 2007; Funk et al., 2008), and water erosion has no relevance in the flat lowlands. A possible thinning effect resulting of an intrusion of subsoil material by tillage can lead to an underestimation of $\mathrm{SOC}$ in the topsoil. Therefore, topsoil and tillage depths need to be observed to exclude such causes of detected SOC changes.

To link topsoil measurements with Aeolian losses previous region-specific direct wind erosion measurements and other erosion studies are advantageous to define a range of usual soil and SOC loss. Bach (2008) measured soil and SOC losses by saltation in laboratory wind tunnel experiments investigating sandy top soil material from the same erosion-affected site as reported in this study. Using the TEAM model (Gregory et al., 2004) the author determined a high erodibility of that soil material resulting in a total soil loss of $13.08 \mathrm{~kg} \mathrm{~m}^{-2}$ within four days in March 1969, and a maximum single-event loss of $5.49 \mathrm{~kg} \mathrm{~m}^{-}$ 2. Hassenpflug (1998) estimated a total soil loss of $10.0-15.0 \mathrm{~kg} \mathrm{~m}^{-2}$ by aerial photograph analysis for the same erosion events and in the same area. In Northwestern Germany Goossens (2004) found $>5 \mathrm{~kg}$ soil $\mathrm{m}^{2}$ eroded at a sandy field (lengths $125-200 \mathrm{~m}$ ) during an erosion event of $11 \mathrm{~h}$. Studying an alluvial sandy soil in Northeastern Germany Funk et al. (2004) determined surface roughness and measured and simulated up to $10.5 \mathrm{~kg} \mathrm{~m}^{-2}$ of single-event total soil loss blown by erosive west winds. The study used the process-based erosion model SWEEP (Hagen et al., 1995) which was validated successfully for German sandy soils (Funk et al. 2004). Measurements and modeling on a $150 \mathrm{~m}$ long field resulted in 35 and $46 \%$ of suspension, respectively. It was possible to show, that after setting the initial conditions very carefully, changing soil surface conditions and corresponding soil losses could be modelled by SWEEP with good accuracy. The studies of Bach (2008) and Funk et al. (2004) are the only available comparisons between measured and modelled soil losses by wind erosion in Germany.

To avoid wind erosion, the surface application of cattle slurry is a widely used erosion control method in agricultural areas with high wind erosion risk in Northern Germany (Duttmann et al., 2011; Bach, 2008; Riksen et al., 2003). Especially liquid cattle manure contains many fibers and adhesive substances forming a stable crust after drying (Riksen et al. in Warren, 2003). Heavy rainfall can destroy the protective effect of these crusts. 
Alternatively, erosion control by surface-applied solid manure or dung (Blanco-Canqui and Lal, 2008; de Rouw and Rajot, 2004b) can be used.

\subsection{SOC and wind erosion}

Wind erosion is a very effective material sorting and SOC-removing process; as a result, fine particles in the suspension transport can be enriched in organic matter (Zobeck and Fryrear, 1986). This is expressed through enrichment ratios (ERs), the ratio of SOC content in the eroded material to the SOC content in the parent soil (Sterk et al., 1996). ERs for SOC are expected to be $\leq 1$ in the saltation layer $(<\approx 30 \mathrm{~cm})$ and $\geq 1$ in the suspension layer $(>\approx 30 \mathrm{~cm})$. Bach (2008) derived an ER of 0.98 in the saltation layer by wind tunnel studies using soil material of site $A$ and surroundings.

A comprehensive overview of the importance of SOC enrichment in dust emissions on a continental scale was provided by Chappell et al. (2013). The authors present results from soil sampling and modeling. In the semiarid Canadian prairies Larney et al. (1998) reported ERs for saltation ranging between 1.02 and 1.05 (25 cm height). At semiarid environments in southwest Niger Sterk et al. (1996) found a saltation ER of 1.33 at $5 \mathrm{~cm}$ height. Funk et al. (2004) described increasing ER with height, ranging from 0.92 to 1.7 from 5 to $45 \mathrm{~cm}$ height at a sandy test site of low SOC stock in Eastern Germany. Similar was observed by Mendez et al. (2011) presenting measured ERs of 0.97 ( $5 \mathrm{~cm}$ height), 1.03 (15 $\mathrm{cm}), 3.7(45 \mathrm{~cm})$ and $4.6(80 \mathrm{~cm})$. Sterk et al. (1996) stated ERs of 2.39 and 3.02 for heights of 26 and $50 \mathrm{~cm}$, respectively. They remarked that those heights include material transported by both, saltation and suspension processes.

Studying the arid region of southern New Mexico Li et al. (2007) found ERs (1.2 m height) between 3.24 without coverage, increasing continuously to 6.33 (75\% cover). Ramsperger et al. (1998) measured ERs of SOC of 3 - 4 for dust samples trapped in 2 and $4 \mathrm{~m}$ height, Funk (1995) estimated an ER of 5 for dust sampled in $6 \mathrm{~m}$ height. ERs depend as well of the parent material's SOC content. For Australia Webb et al. (2012) reported suspension ERs ( $2 \mathrm{~m}$ height) of 1.67 in grass downs, 3.63 at a sand plain and $\sim 7$ at a dune.

Analyzing the SOC losses per area requires greater efforts and is based on flux measurements with a high spatial resolution (Buschiazzo and Funk, 2015) or indirect evidences as radionuclide concentration of ${ }^{137} \mathrm{Cs}$ (Funk et al., 2012). For Australian soils Harper et al. (2010) found average losses of 0.36 and $0.51 \mathrm{~kg} \mathrm{C} \mathrm{m}^{-2}$ eroded by wind, for 1 or 2 years, respectively.

\subsection{Soil monitoring}


The soil properties affected by environmental impacts, e.g. wind erosion, have been observed on long-term soil monitoring sites ("Boden-Dauerbeobachtungsflächen", BDF sites) in Germany since 1985 (Nerger et al., 2016; Prechtel et al., 2009; Schröder et al., 2004; Barth et al., 2001). A detailed description of the BDF-SH SMN (Boden-Dauerbeobachtung Schleswig-Holstein soil monitoring network) methods and quality was provided in Nerger et al. (2016). The BDF-SH SMN was evaluated as highly suitable to detect long-term changes in soil and in farming management.

The BDF sites are part of larger fields and managed by farmers with contractual obligation to report all realized management actions. The top soil material of the BDF is sampled and analyzed at regular time intervals. These sites offer the unique opportunity to study long-term effects on soil properties, especially the gradual degradation by wind erosion, which is difficult to detect at a site itself through short-term measurements. On an international scale, comprehensive wind erosion monitoring networks which include soil and faming monitoring are still in the build-up phase (Webb et al., 2016). Thus, the already existing soil monitoring networks could be used to study the past impact of wind erosion on the soil.

\subsection{Objectives}

The main objective of this study was to investigate whether long-term soil and SOC losses measured at sites of a high-quality soil monitoring network can be explained by wind erosion shown on the use of a process-based wind erosion model. In this long-term context of 10 years wind erosion events were often observed but continuous direct measurements were not possible. Instead, measured long-term soil monitoring and farming data of the peerreviewed BDF-SH SMN were used for study sites without other noteworthy causes of soil and SOC losses, except wind erosion. As the data situation was adequate the use of a physical based wind erosion model, considering both saltation and suspension transport process, was possible. The most important input parameters were determined in the field, including high-resolution wind speed data. Finally, the potentials, uncertainties and limitations 


\section{Material and Methods}

\subsection{Description of the study sites}

178 The monitoring site Leck (site A) was characterized by high SOC losses, possibly due to wind erosion, and therefore selected as a study site. The reference site Schuby (site B) was selected because it features similar soil properties and farming management. Both sites are located in the Geest region in Northern Germany (Table 1 and Figure 1).

182

183
Table 1: Basic geographical and management characteristics of the monitoring sites $A$ and $B$ (LLUR, 2010)

\begin{tabular}{|c|c|c|}
\hline site & A & $\mathrm{B}$ \\
\hline location & Leck & Schuby \\
\hline short coordinates (GK) ${ }^{a}$ & 35066,60621 & 35282,60452 \\
\hline landscape unit & Geest (Schleswiger Vorgeest) & Geest (Schleswiger Vorgeest) \\
\hline $\begin{array}{l}\text { annual mean temp. }\left({ }^{\circ} \mathrm{C}\right) \\
1981-2010\end{array}$ & 8.2 & 8.6 \\
\hline parent material & Weichselian glacifluvial sands & Weichselian sandur sands \\
\hline soil texture ${ }^{b}$ & sandy sand ( $93 \%$ sand, $4 \%$ silt, $2 \%$ clay) & $\begin{array}{c}\text { sandy sand ( } 87 \% \text { sand, } 9 \% \text { silt, } 4 \% \\
\text { clay) }\end{array}$ \\
\hline soil type ${ }^{c}$ & Plaggic Anthrosol & Plaggic Anthrosol \\
\hline historic land use & heathland / plaggen & heathland / plaggen \\
\hline present land use & maize monoculture & crop rotation (maize, grain crops) \\
\hline
\end{tabular}

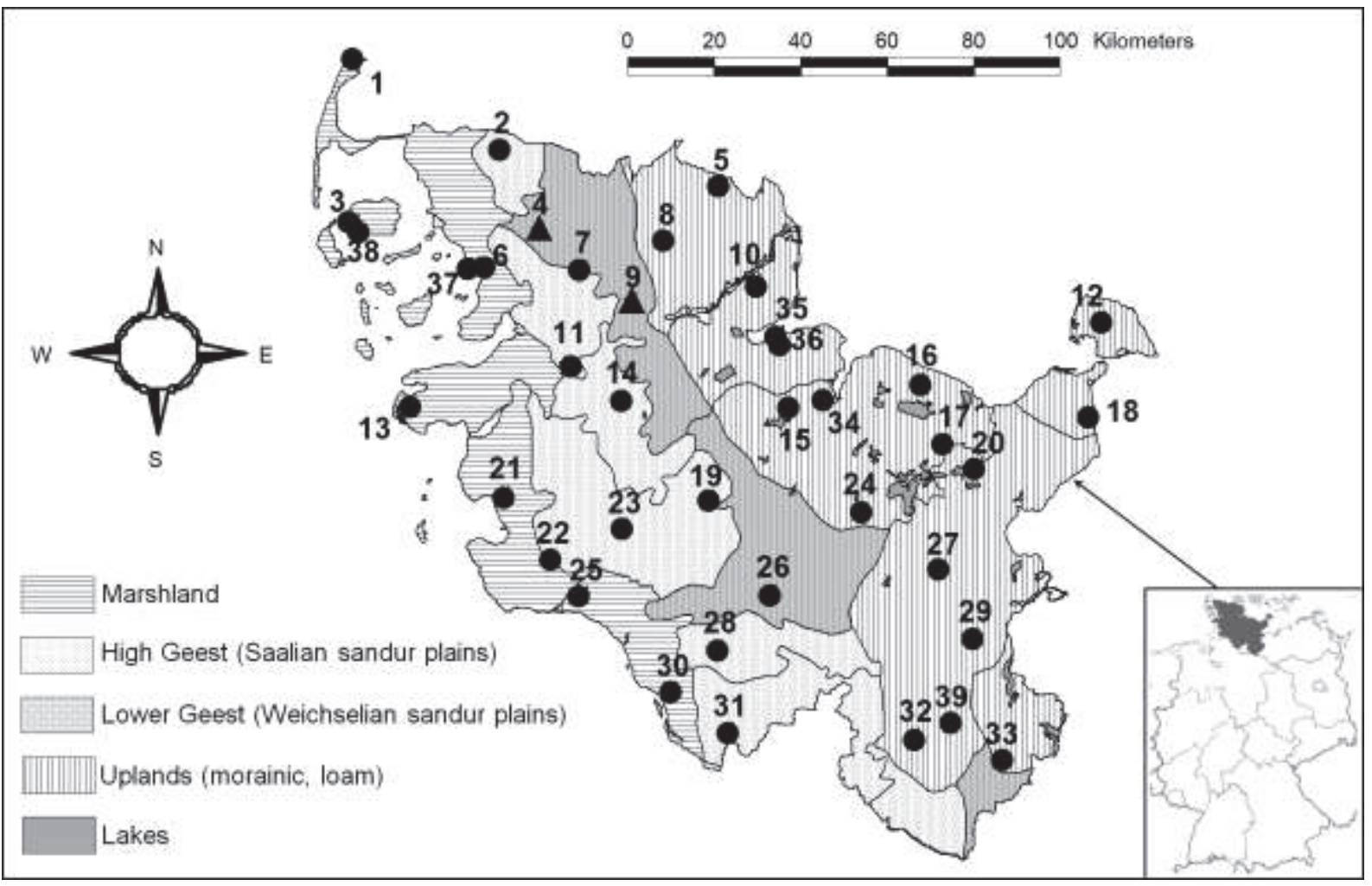

Figure 1: Natural landscape units of Schleswig-Holstein (Northern Germany) and localization of the long-term soil monitoring sites. The study sites $A$ and $B$ are the sites 4 and 9 in the figure (triangle symbols) 
The monitoring sites with a size of 0.1 ha are managed in the same manner as the larger field of which they are part of (Figure 2). The boundaries of the BDF are geodetically marked positions of rocks and magnets in the deeper subsoil. Thus, at the surface there is a continuous transition of the soil from the monitoring sites to the surrounding field.
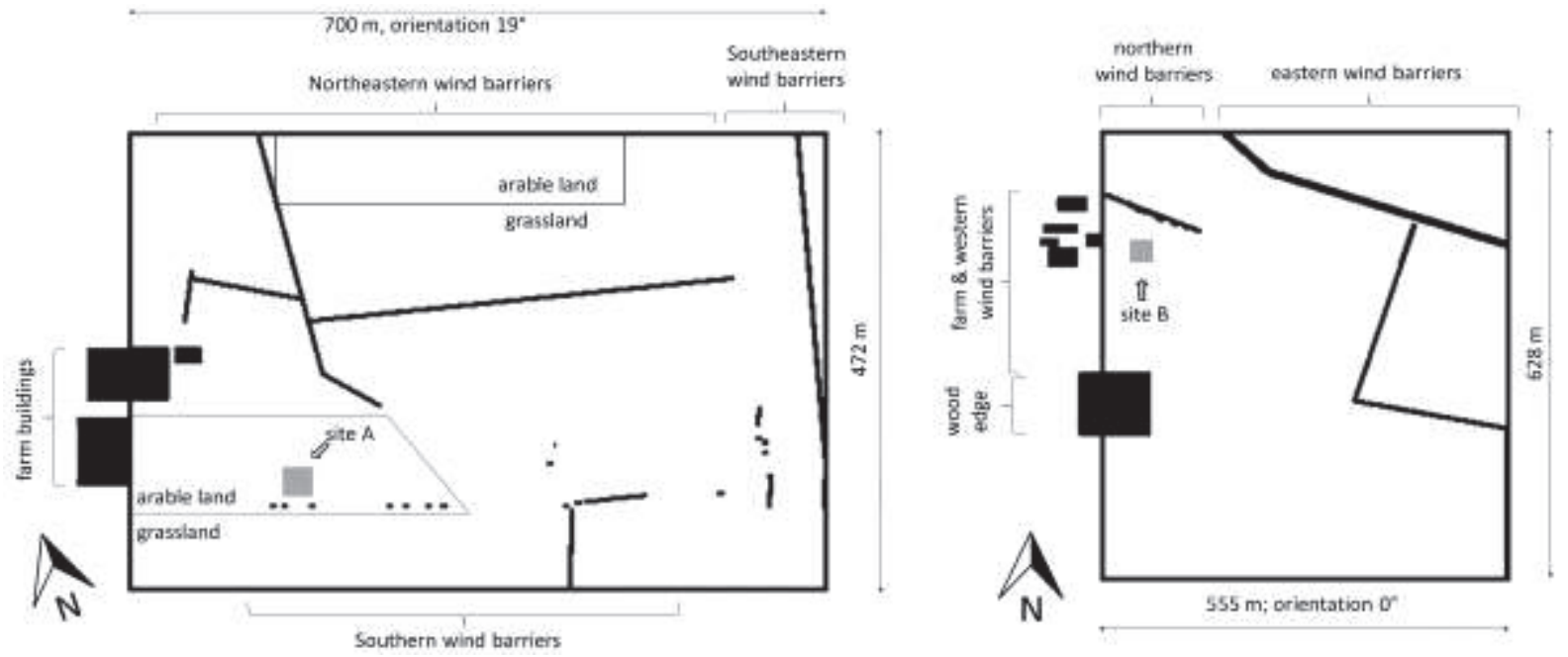

Figure 2: Monitoring sites A (left), B (right) and surrounding areas

Site $A$ is located in the center of a sandy maize monoculture field. The effective field length to the east, the direction where the erosive winds are from, is $125 \mathrm{~m}$. Adjacent to the east there is pasture and finally wind barriers; the total length from site $A$ to the wind barriers in the east is $545 \mathrm{~m}$. Site B has a similar soil texture, more wind barriers close to the monitoring site and tillage perpendicular to the main erosive wind directions. The field length to the east is $340 \mathrm{~m}$. The surrounding situation of both sites remained constant over the time periods considered for modeling.

Erosion control measures were realized using the crust formation effect of surfaceapplied slurry at site A (Table 2). In some years, the slurry was not applied immediately after sowing, thus, on a few days high wind speeds coincided with uncovered soil. Heavy rainfall was able to destroy the adhesive effect, as documented by the farmer in the management database (LLUR, 2010) and regarded in the calculations. Referring to German Meteorological Service (DWD) heavy rainfall is defined as daily precipitation amount exceeding $25 \mathrm{~mm}$, a value which was used in the study to consider the slurry crust as ineffective. After harvest crop residues remained on the field. In addition to the natural weed infestation it formed a soil cover until stubble cultivation in spring. Since 2007 solid cattle manure was surface-applied as erosion control at site A. This cover was not affected by heavy rainfall (LLUR, 2010). In contrast, at site B no erosion control took place and the farming management was partly different (Table 2). 
Table 2: Selected major management characteristics of the monitoring sites A and B from 1991 - 2009 (LLUR, 2010)

\begin{tabular}{|c|c|c|}
\hline site & $A$ & B \\
\hline main crops & silage maize monoculture & $\begin{array}{l}\text { crop rotation including maize; } \\
\text { years } 2002 \text { to } 2005 \text { and } 2008 \text { : } \\
\text { wintercrops only, } \\
\text { no crop cultivation in spring }\end{array}$ \\
\hline catch crops and mulch & none & none \\
\hline crop residues & $\begin{array}{c}\text { remained on the field in winter; incorporated in } \\
\text { spring by cultivator or disk harrow (before } \\
\text { ploughing) }\end{array}$ & surface-applied in autumn \\
\hline ploughing & annually, from 2007 conservation tillage & 1-2 times per year \\
\hline ploughing depth & $30 \mathrm{~cm}$ until 2002; $25 \mathrm{~cm}$ since 2003 & $\begin{array}{c}25 \mathrm{~cm} \text { in spring, } 30 \mathrm{~cm} \text { in autumn } \\
\text { (some years) }\end{array}$ \\
\hline sowing time & 1-5 days after seedbed preparation & 2-6 days after seedbed preparation \\
\hline $\begin{array}{l}\text { tillage spacing and } \\
\text { orientation }\end{array}$ & $75 \mathrm{~cm}, \mathrm{WNW}-\mathrm{ESE}$ & $75 \mathrm{~cm}, \mathrm{~N}-\mathrm{S}$ \\
\hline $\begin{array}{l}\text { incorporated organic } \\
\text { fertilizer }\end{array}$ & $35-45 \mathrm{~m}^{3} \mathrm{ha}^{-1} \mathrm{a}^{-1}$ & $35-40 \mathrm{~m}^{3} \mathrm{ha}^{-1} \mathrm{a}^{-1}$ \\
\hline $\begin{array}{c}\text { erosion control after } \\
\text { sowing }\end{array}$ & $\begin{array}{l}\text { always on the same day or } 1 \text { day after sowing; } \\
\text { surface fixation by cattle slurry }\left(5-15 \mathrm{~m}^{3} \mathrm{ha}^{-1} \mathrm{a}^{-1}\right) \\
\text { until 2006; from } 2007 \text { surface application of solid } \\
\text { manure }\end{array}$ & none \\
\hline $\begin{array}{l}\text { potential erosion } \\
\text { exposure }\end{array}$ & $\begin{array}{l}\text { spring: time from stubble cultivation, ploughing, } \\
\text { about } 2.5 \text { to } 3 \text { months; coincides with dr }\end{array}$ & $\begin{array}{l}\text { owing, until } 2 \text { months after; in total } \\
\text { and strong eastern winds }\end{array}$ \\
\hline
\end{tabular}

All laboratory results are obtained from the long-term soil monitoring program BDFSH SMN (LLUR, 2010). Data of three sampling campaigns between October to November in 1990, 1999 and 2009 were used for the analysis. The sampling and measurement procedure followed standardized and scientific soil monitoring techniques and was described in detail in Nerger et. al. (2016). Basically, three composite samples were taken from 18 single points per campaign and study site. Only topsoil material was taken and depths documented. The rock fraction was determined by volume in the field and converted to mass fractions using conversion tables in Ad-Hoc-AG Boden (2005). SOC stock calculation, uncertainty determination and laboratory procedures were as described in Nerger et al. (2016). Additionally, saturated hydraulic water conductivity was measured in constant-head mode after DIN 19683-9:1998-05.

\subsection{Calculation of management SOC balances}

Conventional management SOC balances were calculated annually using the siteadjusted method of Kolbe (2010). The calculation is based on the management documentation of main crops, residue management and organic amendments. Cultivated 
crops are considered as a SOC-draining factor whereas catch crops, organic amendments and residues left on the field increase SOC balance. The method offers default values for these factors, derived from German long-term field trials.

The method was chosen because it is a substantial improvement to former methods and has been site-specific adjusted. $S O C / N_{\text {tot }}$ ratio and texture as soil-borne input are considered, referring to Springob and Kirchmann (2003) who stated this ratio as an indicator for the high inert SOC pool of sandy soils of heathland and Plaggen history which are present at the study sites $A$ and $B$.

\subsection{The wind erosion model SWEEP}

\subsubsection{Brief description of the model and its application}

To reproduce the measured topsoil loss, the model SWEEP (Single-event Wind Erosion Evaluation Program; version 1.2.12; Hagen, 2004) was chosen, because it was validated successfully for sandy soils of Northeastern Germany by Funk et al. (2004), which are comparable to those of Schleswig-Holstein. SWEEP is an advancement of the stand-alone erosion submodel of WEPS (Hagen et al., 1995, 1991; Hagen, 2004; Li et al., 2014). The site-specific total soil loss and deposition are modelled and creep/saltation and suspension transport are distinguished. Data input and output is from sub-hourly (e.g. wind speed) to daily (e.g. erosion results) time steps.

The model runs cover the time periods of topsoil measurements from 1999 to 2009. Each year the relevant model period started at the first day of tillage in the year and lasted until 60 days after sowing, thus up to 75 days per year in total. Days featuring erosion control measures were not erosive (LLUR, 2010) and thus not modeled. Dust emissions by tillage were excluded, because they were considered as negligible (cf. section 1.1).

\subsubsection{Field geometry and wind barriers}

The entire field, neighboring areas and wind barriers of the study sites (Figure 2) were included in the spatial model setup. A grid size was chosen in which each BDF site was represented of nine grid cells $(3 \times 3)$ as part of the total modeling area. As modeling results solely the grid cells of the monitoring sites ( $0.1 \mathrm{ha})$ were used. The different height, length, width and porosity of wind barriers were also characterized. For grass, tree lines and shrubs the porosity was set to 0.5 , according to Vigiak et al. (2003) and Hagen et al. (1981); farm buildings, wood and solid barriers were considered with lesser porosities or were set to zero. Height, length and width of hedges and trees were determined in field campaigns. The wind 
barriers were constantly present over the monitored time period, although tree growth was not considered in this study.

\subsubsection{Weather related parameters}

The weather station in Leck (distance: $14 \mathrm{~km}$ ) was selected for site $A$, data from the urban station in Schleswig (distance: $7 \mathrm{~km}$ ) were used at site B. The stations are equivalent for the study sites as the comparison with verified and region-specific data of wind maps of a $200 \mathrm{~m}$ resolution (DWD, 2010) revealed that both sites and stations are characterized by a longterm average annual wind speed of $5.1-5.4 \mathrm{~m} / \mathrm{s}$.

Wind speed data were available as 10-minute- and wind direction as hourly averages supplied by the German Meteorological Service (DWD). Aerodynamic roughness was estimated according to the classification of Traup and Kruse (1996) and aerial photos of the surroundings of the station.

The surface water content was calculated hourly from precipitation data of both weather stations. According to the very sandy soil texture and high soil hydraulic conductivity values of both sites $\left(2.2-8.8 \mathrm{~cm} \mathrm{~h}^{-1}\right)$, precipitation was assumed to infiltrate immediately (Blume et al., 2002) and the soil surface to be dried up within two hours from the surface. Surface water content of the upper $5 \mathrm{~mm}$ (Hagen et al., 1995) of soil layer was calculated as follows:

$$
S W C=\frac{0.1 * C U M P_{h}}{0.5 * D B D}
$$

Where: SWC $=$ surface water content $\left[\mathrm{g} \mathrm{g}^{-1}\right] ; \mathrm{CUMP}_{\mathrm{h}}=$ hourly precipitation amount $[\mathrm{mm}]$ equivalent to $\left[\mathrm{m}^{-2}\right]$ or $\left[\mathrm{kg} \mathrm{m}{ }^{-2}\right] ; \mathrm{DBD}=$ dry bulk density $\left[\mathrm{g} \mathrm{cm}^{-3}\right]$

\subsubsection{Soil layer, surface and biomass parameters}

Many constant SWEEP input parameters (Table 3) were determined in the field or in the laboratory, others calculated due to reliable sources. The study of Funk et al. (2004) for German sandy soils was important to confirm the field-determined range of initial random roughness and oriented roughness (ridge height) as well as the description of their declines after precipitation and erosion events. 
Table 3: Setup of selected constant input parameters in SWEEP of the monitoring sites A and B

\begin{tabular}{|c|c|c|c|c|}
\hline constant parameters & unit & site $\mathrm{A}$ & site $B$ & calculation/estimation method; source \\
\hline initial random roughness & $\mathrm{mm}$ & 4 & 6 & \multirow{2}{*}{ field observation; Funk et al. (2004) } \\
\hline initial ridge height & $\mathrm{mm}$ & 25 & 35 & \\
\hline row spacing & $\mathrm{m}$ & 0.75 & 0.75 & \multirow{2}{*}{ LLUR (2010) } \\
\hline ridge orientation & deg & 109 & 0 & \\
\hline ridge spacing & $\mathrm{mm}$ & 150 & 150 & \multirow{2}{*}{ LLUR (2010), Hagen et al. (1995) } \\
\hline ridge width & $\mathrm{mm}$ & 100 & 100 & \\
\hline aerodynamic roughness & $\mathrm{mm}$ & 40 & 300 & \multirow{5}{*}{$\begin{array}{l}\text { estimation according to Traup and Kruse } \\
\text { (1996) and aerial photos } \\
\text { field measurement } \\
\text { estimation from grain-size distribution } \\
\text { curve (Blume et al. 2002) } \\
\text { Skidmore and Layton (unpub.) in: Hagen } \\
\text { et al. (1995) } \\
\text { Skidmore and Layton (1992) in: Hagen et } \\
\text { al. (1995) }\end{array}$} \\
\hline rock volume fraction & $m^{3} m^{-3}$ & 0 & 0.15 & \\
\hline initial very fine sand fraction & $\mathrm{Mg} \mathrm{Mg}^{-1}$ & 0.2 & 0.1 & \\
\hline initial aggregate density & $\mathrm{Mg} \mathrm{m}^{-3}$ & 1.80 & 1.80 & \\
\hline initial dry aggregate stability & $\ln \left(\mathrm{J} \mathrm{kg}^{-1}\right)$ & 1.17 & 1.42 & \\
\hline initial GMD of aggregate sizes & $\mathrm{mm}$ & 1.02 & 3.19 & \multirow{4}{*}{ Farres (1978) in: Hagen et al. (1995) } \\
\hline initial GSD of aggregate sizes & $\mathrm{mm} \mathrm{mm}^{-1}$ & 10.30 & 14.76 & \\
\hline initial minimum aggregate size & $\mathrm{mm}$ & 0.01 & 0.01 & \\
\hline initial maximum aggregate size & $\mathrm{mm}$ & 16.44 & 75.20 & \\
\hline $\begin{array}{l}\text { adjusted sand fraction (after prev. erosion } \\
\text { event = a.p.e.e.) }\end{array}$ & $\mathrm{Mg} \mathrm{Mg}^{-1}$ & 1.00 & 1.00 & \multirow{8}{*}{ equations $(2 ; 3)$ of this study } \\
\hline adjusted very fine sand fraction (a.p.e.e.) & $\mathrm{Mg} \mathrm{Mg}^{-1}$ & 0 & 0 & \\
\hline adjusted aggregate density (a.p.e.e.) & $\mathrm{Mg} \mathrm{m}^{-3}$ & 1.80 & 1.80 & \\
\hline adjusted dry aggregate stability (a.p.e.e.) & $\ln \left(\mathrm{J} \mathrm{kg}^{-1}\right)$ & 0.85 & 0.85 & \\
\hline adjusted GMD of aggregate sizes (a.p.e.e.) & $\mathrm{mm}$ & 1.00 & 1.00 & \\
\hline adjusted GSD of aggregate sizes (a.p.e.e.) & $\mathrm{mm} \mathrm{mm}^{-1}$ & 1.01 & 1.01 & \\
\hline $\begin{array}{l}\text { adjusted minimum aggregate size } \\
\text { (a.p.e.e.) }\end{array}$ & $\mathrm{mm}$ & 0.10 & 0.10 & \\
\hline $\begin{array}{l}\text { adjusted maximum aggregate size } \\
\text { (a.p.e.e.) }\end{array}$ & $\mathrm{mm}$ & 2.00 & 2.00 & \\
\hline Soil wilting point water content & $\mathrm{Mg} \mathrm{Mg}^{-1}$ & 0.09 & 0.16 & LLUR (2010), field measurement \\
\hline $\begin{array}{l}\text { effective crust after applying slurry as } \\
\text { erosion control (until 2006) }\end{array}$ & $m^{2} m^{-2}$ & 1.0 & - & \multirow{3}{*}{$\begin{array}{l}\text { LLUR (2010), field observation; soil cover } \\
\text { of solid manure comparable to Wagner } \\
\text { and Nelson (1995) }\end{array}$} \\
\hline $\begin{array}{l}\text { residue flat cover after applying solid } \\
\text { manure as erosion control (from 2007) }\end{array}$ & fraction & 1.0 & - & \\
\hline residue flat cover of flat maize stubbles & fraction & 0.25 & - & \\
\hline surface crust density & $\mathrm{Mg} \mathrm{m}^{-3}$ & 1.80 & 1.80 & $\begin{array}{l}\text { Skidmore and Layton (unpub.) in: Hagen } \\
\text { et al. (1995) }\end{array}$ \\
\hline surface crust stability & $\ln \left(\mathrm{J} \mathrm{kg}^{-1}\right)$ & 1.17 & 1.42 & Zobeck (1991) in: Hagen et al. (1995) \\
\hline
\end{tabular}
various authors as documented in the WEPS technical manual (Hagen et al., 1995). Events of erosion and precipitation $>10 \mathrm{~mm}$ affect soil layer and surface properties. Thus, after each event some soil layer and surface parameters had to be updated (Hagen, 2008) using the SWEEP update function. 
Table 4: Sources of selected variable input parameters in SWEEP for the monitoring sites A and B

\begin{tabular}{|c|c|c|}
\hline variable parameters & unit & calculation/estimation method; source \\
\hline \multirow{3}{*}{$\begin{array}{c}\text { decline of random roughness (after } \\
\text { precipitation) } \\
\text { decline of ridge height (after } \\
\text { precipitation) } \\
\text { decline of random roughness (after } \\
\text { erosion event) } \\
\text { decline of ridge height (after erosion } \\
\text { event) }\end{array}$} & $\mathrm{mm}$ & Potter (1990) in: Hagen et al. (1995) \\
\hline & $\mathrm{mm}$ & Lyles and Tatarko (1987) in: Hagen et al. (1995) \\
\hline & $\mathrm{mm}$ & SWEEP subdaily results (update function) \\
\hline initial surface crust thickness & $\mathrm{mm}$ & Farres (1978) in: Hagen et al. (1995) \\
\hline initial surface crust fraction & $m^{2} m^{-2}$ & \multirow{3}{*}{ Zobeck and Popham (1992) in: Hagen et al. (1995) } \\
\hline initial loose erodible fraction & $m^{2} m^{-2}$ & \\
\hline initial loose erodible mass & $\mathrm{kg} \mathrm{m}^{-2}$ & \\
\hline decline of surface crust thickness & $\mathrm{mm}$ & \multirow{4}{*}{ SWEEP subdaily results (update function) } \\
\hline decline of surface crust fraction & $m^{2} m^{-2}$ & \\
\hline decline of loose erodible fraction & $m^{2} m^{-2}$ & \\
\hline decline of loose erodible mass & $\mathrm{kg} \mathrm{m}^{-2}$ & \\
\hline changed loose erodible mass & $\mathrm{kg} \mathrm{m}^{-2}$ & equations $(2 ; 3)$ of this study \\
\hline residue flat cover & $m^{2} m^{-2}$ & Wagner and Nelson (1995); field observation \\
\hline $\begin{array}{l}\text { growing crop height } \\
\text { SAI (incl. stem diameter, plants per } \mathrm{m}^{2} \text { ) } \\
\text { growing crop leaf area index }\end{array}$ & $\begin{array}{c}m \\
m^{2} m^{-2} \\
m^{2} m^{-2}\end{array}$ & $\begin{array}{l}\text { sowing and yield data of the management database (LLUR, } \\
\text { 2010); growth stages of maize plants of Armbrust and Lyles } \\
\text { (1985); growing degree days concept of Hagen et al. (1995) }\end{array}$ \\
\hline
\end{tabular}

330

331

332

333

334

335

336

337

338

339

340

341

342

343

344

345

However, not all necessary updates for the needs of this study are included in the update function, e.g. the changed texture in the uppermost centimeter after erosion events. If such events were characterized by high suspension loss and low saltation loss, soil texture near surface shows depletion of material susceptible to suspension transport (López, 1998; de Rouw and Rajot, 2004a). These losses were subtracted from soil stocks of those materials. As a first step material susceptible for suspension was defined according to Hagen et al. (1995) as the clay, silt and very fine sand fraction (Table 5).

Table 5: Estimated stocks of process-specified susceptible material for the uppermost layer of $1 \mathrm{~cm}$ from Ap horizon of the monitoring sites $\mathrm{A}$ and $\mathrm{B}$

\begin{tabular}{llll}
\hline & unit & site & value \\
\hline $\begin{array}{l}\text { stock of material susceptible for } \\
\begin{array}{l}\text { suspension (very fine sand, silt, clay) of } \\
\text { the uppermost layer of } 1 \mathrm{~cm}\end{array}\end{array}$ & $\mathrm{~kg} \mathrm{~m}^{-2}$ & $\mathrm{~A}$ & 3.47 \\
& & $\mathrm{~B}$ & 3.10 \\
$\begin{array}{l}\text { stock of material susceptible for saltation } \\
\begin{array}{l}\text { (sand without very fine sand) of the } \\
\text { uppermost layer of } 1 \mathrm{~cm}\end{array}\end{array}$ & $\mathrm{~kg} \mathrm{~m}^{-2}$ & $\mathrm{~A}$ & 9.53 \\
\hline
\end{tabular}

The SWEEP model is actually not applicable for multiple soil layers. Thus, the resulting superficial sand layer was modeled as loose erodible mass (LEM) above an impermeable crust (L.E. Wagner, 2011, personal communication). The calculation for the thickness of the remaining pure sand layer and the LEM was derived as follows: 


$$
T_{L A Y E R}=\frac{\text { SOIL_LOSS }_{\text {SUSP }}}{\text { SOIL_STOCK }_{\text {SUSP }}}-\frac{\text { SOIL_LOSS }_{\text {SALT }}}{\text { SOIL_STOCK }_{S A L T}}
$$

2.5 Comparing SOC losses from measurement, balances and modeling results

As a first step topsoil SOC stocks at the beginning and the end of the test period were calculated as described in section 2.2. The annually calculated SOC balances were cumulated for the test period and added to the topsoil SOC stock losses (Equation 4) resulting in the total SOC loss through wind erosion. Calculating SOC transport by saltation of each event the ER of 0.98 derived from wind tunnel experiments for local soil material from Bach (2008) was multiplied with the modeled soil losses (Equation 5). The resulting sum of SOC loss by saltation of the whole test period was subtracted from overall SOC loss (Equation 6). The remaining SOC loss was regarded to be lost by suspension.

Assigning the entire measured topsoil SOC loss to wind erosion was possible as all other causes of SOC loss could be excluded (cf. section 1.1).

SOC loss by suspension was allocated weighted to the suspension soil loss of each erosion event. Thus, a suspension ER resulted for the whole test period whereas SOC loss was pointed out for single events considering reduced SOC contents after every erosion event.

$S O C_{-} L O S S_{\text {TOTAL }}=S O C_{-} C H A N G E_{A p ; 1999}$ to $2009+\sum_{\text {year } 1}^{\text {year } 10}$ SOC_BALANCE $E_{\text {ANNUAL }}$

$S O C_{-} L O S S_{S A L T}=\sum_{i=1}^{n} S O I L_{-} L O S S_{S A L T} *\left(S O C_{-} C O N C_{A p ; 1999} * E R_{S A L T}\right)$

Where:

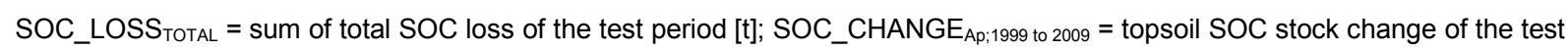
period, means from 1999 to 2009 [t]; SOC_BALANCE $E_{\text {ANNuAL }}=$ annual SOC balances of the test period [t]; SOC_LOSS salt $_{\text {s }}$ sum

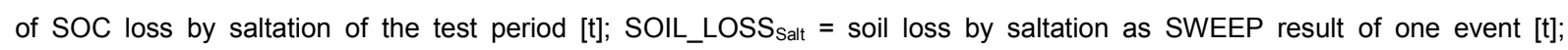
SOC_CONC = initial SOC concentration measured at the beginning of the test period [\%]; ER SALT $=$ enrichment ratio saltation $\left(=0.98 ;\right.$ Bach (2008); SOC_LOSS $S_{\text {susp }}=$ sum of SOC loss by suspension of the test period [t] 


\subsection{Modeling variations}

Modeling variations were assessed for the most sensitive parameters mentioned in Hagen et al. (1999) and Feng \& Sharratt (2005) for site A. Using the SWEEP threshold friction speed of $8 \mathrm{~m} \mathrm{~s}^{-1}$ the effect of wind speed variations of $\pm 5 \%$ on wind values was calculated, whose relation is similar between wind speed and soil loss (Fryrear et al., 1998).

The resulting wind value deviations represent the potential total soil loss deviations. In a second run, random and oriented roughness were varied by 25 and $20 \%$, respectively. Finally, the time needed to dry up the soil surface after an erosion event was varied from two hours to four hours.

\section{Results}

\subsection{Results of topsoil measurements}

The results of the topsoil measurements (LLUR, 2010) are listed in Table 6. Grain size distribution shows an erosion-susceptible fine sand fraction of $50 \%$ at site A. It declined from 1999 to 2009. In accordance with the very sandy texture of the sites, hydraulic water conductivity was high and reached $2.2-8.8 \mathrm{~cm} \mathrm{~h}^{-1}$.

Table 6: Laboratory characterization of topsoil samples of the monitoring sites A and B. Measurement campaigns in October/November of the years $1990\left(1^{\text {st }}\right), 1999\left(2^{\text {nd }}\right)$ and $2009\left(3^{\text {rd }}\right)$

\begin{tabular}{|c|c|c|c|c|c|c|c|c|}
\hline \multirow[b]{2}{*}{ soil property } & \multirow[b]{2}{*}{ unit } & \multirow[b]{2}{*}{ site } & \multicolumn{2}{|c|}{$1^{\text {st }}$ campaign } & \multicolumn{2}{|c|}{$2^{\text {nd }}$ campaign } & \multicolumn{2}{|c|}{$3^{\text {rd }}$ campaign } \\
\hline & & & mean & $\pm \mathrm{SD}$ & mean & $\pm S D$ & mean & $\pm S D$ \\
\hline \multirow{2}{*}{$\begin{array}{l}\text { Ap horizon soil mass } \\
\text { (excluding rocks) }\end{array}$} & \multirow{2}{*}{$\begin{array}{c}\mathrm{kg} \mathrm{m}^{-2} \\
\text { (for } 0.1 \mathrm{ha} \text { ) }\end{array}$} & $A$ & 429.3 & 15.82 & 390.0 & 23.43 & 340.6 & 14.25 \\
\hline & & $\mathrm{B}$ & 344.3 & 0.00 & 338.3 & 10.31 & 335.9 & 3.46 \\
\hline \multirow{2}{*}{$\begin{array}{c}\text { SOC } \\
\text { concentration }\end{array}$} & \multirow{2}{*}{$\%$} & A & 2.53 & 0.10 & 2.27 & 0.09 & 1.88 & 0.04 \\
\hline & & $\mathrm{B}$ & 3.64 & 0.32 & 4.02 & 0.22 & 3.70 & 0.25 \\
\hline \multirow{2}{*}{$\mathrm{SOC} / \mathrm{N}_{\text {tot }}$ ratio } & \multirow{2}{*}{$\begin{array}{l}\text { dimension- } \\
\text { less }\end{array}$} & $A$ & 13.9 & - & 15.2 & - & 13.4 & - \\
\hline & & $\mathrm{B}$ & 15.5 & - & 20.5 & - & 17.4 & - \\
\hline \multirow{2}{*}{ sand $(63-<2000 \mu \mathrm{m})$} & \multirow{2}{*}{ Vol\% } & A & 92.63 & 0.48 & 93.23 & 0.38 & 90.67 & 0.55 \\
\hline & & $\mathrm{B}$ & 87.13 & 0.78 & 86.73 & 0.68 & 87.93 & 0.40 \\
\hline \multirow{2}{*}{ fine sand $(63-<200 \mu \mathrm{m})$} & \multirow{2}{*}{ Vol\% } & $A$ & 49.97 & 2.51 & 51.07 & 1.42 & 47.13 & 2.15 \\
\hline & & B & 29.63 & 1.66 & 31.50 & 2.04 & 28.10 & 1.25 \\
\hline \multirow{2}{*}{ silt $(2-<63 \mu \mathrm{m})$} & \multirow{2}{*}{ Vol\% } & $A$ & 4.52 & 0.44 & 4.40 & 0.36 & - & - \\
\hline & & $\mathrm{B}$ & 8.50 & 0.55 & 9.30 & 0.26 & 8.07 & 0.47 \\
\hline \multirow{2}{*}{ clay $(<2 \mu \mathrm{m})$} & \multirow{2}{*}{ Vol\% } & A & 2.85 & 0.36 & 2.27 & 0.64 & - & - \\
\hline & & $\mathrm{B}$ & 4.37 & 0.37 & 4.03 & 0.81 & 4.00 & 0.10 \\
\hline \multirow{2}{*}{ silt+clay $(<63 \mu \mathrm{m})$} & \multirow{2}{*}{ Vol\% } & $A$ & - & - & - & - & 9.33 & 0.55 \\
\hline & & $\mathrm{B}$ & - & - & - & - & - & - \\
\hline \multirow{2}{*}{ dry bulk density } & \multirow{2}{*}{$\mathrm{g} \mathrm{cm}^{-3}$} & $A$ & 1.37 & - & 1.30 & 0.08 & 1.21 & 0.05 \\
\hline & & $\mathrm{B}$ & 1.35 & - & 1.33 & 0.04 & 1.33 & 0.05 \\
\hline \multirow{2}{*}{ topsoil depth } & \multirow[b]{2}{*}{$\mathrm{cm}$} & $A$ & 31.3 & 1.2 & 30.0 & 1.3 & 28.2 & 1.2 \\
\hline & & $\mathrm{B}$ & 30.0 & 0.3 & 30.0 & 0.3 & 29.8 & 0.3 \\
\hline \multirow{2}{*}{ hydraulic water conductivity } & \multirow{2}{*}{$\mathrm{cm} \mathrm{h}^{-1}$} & $A$ & - & - & 8.8 & 7.3 & 6.3 & 2.4 \\
\hline & & $\mathrm{B}$ & - & - & 2.2 & 0.4 & 2.5 & 1.2 \\
\hline
\end{tabular}


Originally both sites were characterized by high SOC stocks of over $10.0 \mathrm{~kg} \mathrm{~m}^{-2}$ 408 (Figure 3). From 1999 to 2009 averaged topsoil depth, dry bulk density and SOC

409

410

411

412

413

414

415

416

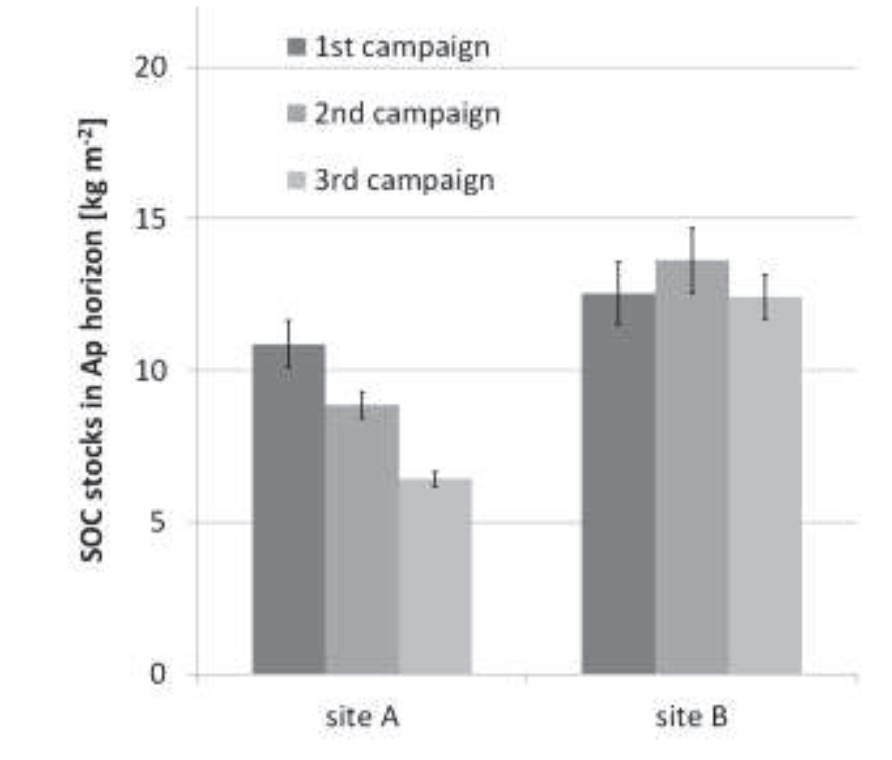

417

418

419

420

421

422

423

424

425

426

427

428

429

430

431

432 concentration declined at site A. Thus, soil mass declined by $49.37 \mathrm{~kg} \mathrm{~m}^{-2}$ and SOC stocks significantly by $2.44 \mathrm{~kg} \mathrm{~m}^{-2}$. Considering standard deviation minimum, loss of SOC stock was $1.76 \mathrm{~kg} \mathrm{~m}^{-2}$. Already prior to the modeling period (1990 to 1999) the significant loss of SOC stock was $2.01 \mathrm{~kg} \mathrm{~m}^{-2}$. At the reference site $B$ the averaged topsoil depths and dry bulk density remained nearly constant. Thus, only a very small soil loss of $2.42 \mathrm{~kg} \mathrm{~m}^{-2}$ was measured; SOC changes were insignificant.

Figure 3: SOC stocks in $\mathrm{kg} \mathrm{m}^{-2}$ for the study sites A and B. Measurement campaigns in October/November of the years 1990 $\left(1^{\text {st }}\right), 1999\left(2^{\text {nd }}\right)$ and $2009\left(3^{\text {rd }}\right)$

\subsection{Results of management SOC balances}

Table 7 shows calculated conventional annual farming management SOC balances based on main crops of the study sites. The total sum of SOC balances for all years was $0.15 \mathrm{~kg} \mathrm{~m}^{-}$ 2 at site $A$ and $0.35 \mathrm{~kg} \mathrm{~m}^{-2}$ at site B. The method of site-adjusted SOC balance (Kolbe, 2010) implies that SOC-consuming crops influence sandy sites to a lesser extent because they have a high turnover of organic carbon. Additionally, organic fertilizers were applied regularly by the farmers. Therefore, these sites mostly feature neutral or positive SOC balances. Compared to the SOC losses the applied amount of organic carbon by liquid and solid manure is low $\left(<0.05 \mathrm{~kg} \mathrm{~m}^{-2} \mathrm{a}^{-1}\right)$. 
Table 7: Main crops and SOC balances in $\mathrm{kg} \mathrm{m}^{-2}$ 1999-2009 for the monitoring sites A and B; calculated using the management data of LLUR (2010) with the side-adjusted method (Kolbe, 2010).

438

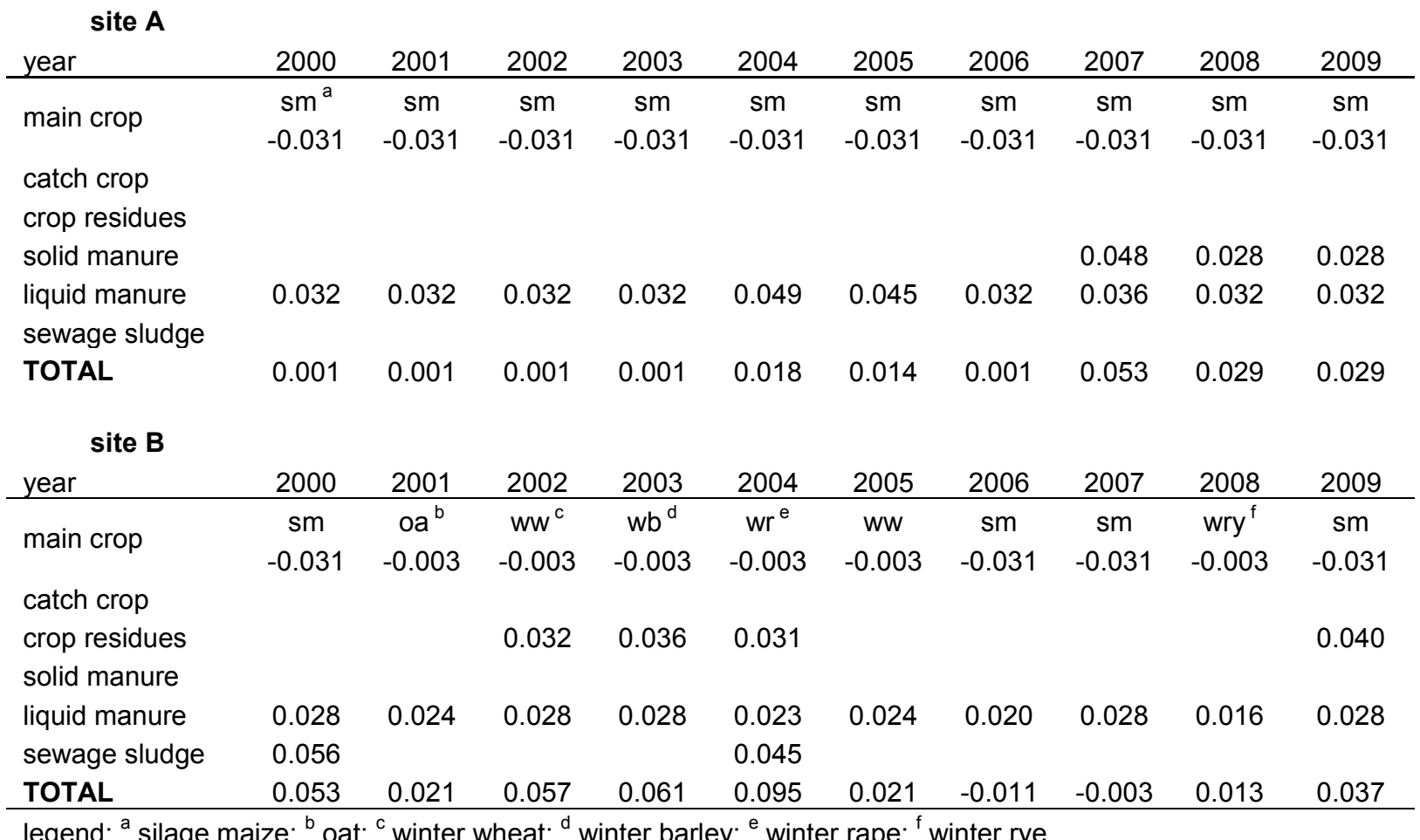

439

440

441

442

443 Model results for site A (Table 8) found 16 erosion days within a ten-year period. The 444 majority of erosion events (10 out of 16) and the highest calculated single event soil loss of $44512.64 \mathrm{~kg} \mathrm{~m}^{-2}$ were related to easterly winds. In the whole test period $48.93 \mathrm{~kg} \mathrm{~m}^{-2}$ of soil was 446 estimated to be eroded by wind from the 0.1 ha monitoring site. This is in very good 447 agreement with the balanced topsoil loss of $49.37 \mathrm{~kg} \mathrm{~m}^{-2}$ for the ten-year period (1999-2009). 448 Excluding negligible erosion events of $100 \%$ creep/saltation transport, soil loss through 449 easterly winds was transported between 61-99 \% by suspension. Due to a smaller effective 450 field length and/or more wind barriers saltation's share was higher (20-50\%) at erosion 451 events of southerly, westerly and northeasterly winds. The overall weighted creep/saltation to 452 suspension ratio was 22:78. 
Table 8: Estimated variable parameters, model results and projected SOC loss for the test period 1999-2009 of the monitoring sites A and B.

\begin{tabular}{|c|c|c|c|c|c|c|c|c|c|c|c|c|c|c|c|c|c|c|c|c|c|c|}
\hline & & \multicolumn{5}{|c|}{ soil surface properties } & \multicolumn{4}{|c|}{ biomass properties } & \multicolumn{3}{|c|}{ weather related properties } & \multicolumn{7}{|c|}{ predicted soil loss for the study sites ( $0.1 \mathrm{ha})$} & \multicolumn{2}{|c|}{ est. SOC loss } \\
\hline date & $\underset{\mathrm{a}}{\mathrm{DALTO}}$ & $\begin{array}{c}\text { random } \\
\text { rough- } \\
\text { ness }\end{array}$ & $\begin{array}{l}\text { ridge } \\
\text { height }\end{array}$ & $\begin{array}{l}\text { surface } \\
\text { crust } \\
\text { fraction }\end{array}$ & $\begin{array}{l}\text { loose } \\
\text { erod. } \\
\text { fraction }\end{array}$ & $\begin{array}{l}\text { loose } \\
\text { erod. } \\
\text { mass }\end{array}$ & $\begin{array}{l}\text { residue } \\
\text { flat } \\
\text { cover }\end{array}$ & $\begin{array}{l}\text { grow. } \\
\text { crop } \\
\text { height }\end{array}$ & $\begin{array}{l}\text { stem } \\
\text { area } \\
\text { index }\end{array}$ & $\begin{array}{c}\text { leaf } \\
\text { area } \\
\text { index }\end{array}$ & $\underset{b}{\operatorname{CUMP}}$ & $\underset{c}{S W C}$ & $\begin{array}{l}\text { wind } \\
\text { direct- } \\
\text { ion }\end{array}$ & $\begin{array}{c}\text { mean } \\
\text { total } \\
\text { soil } \\
\text { loss } \\
\end{array}$ & $\begin{array}{c}\text { grid } \\
\text { varia- } \\
\text { bility }\end{array}$ & $\begin{array}{r}\mathrm{cr} \\
\text { saltat }\end{array}$ & l loss & $\begin{array}{r}\text { susp } \\
\text { IC }\end{array}$ & $\begin{array}{l}\text { nsion } \\
\text { s }\end{array}$ & $\mathrm{T}_{\text {LAYER }}^{\mathrm{d}}$ & $\begin{array}{l}\text { salt- } \\
\text { ation } \\
E R= \\
0.98\end{array}$ & $\begin{array}{c}\text { suspen- } \\
\text { sion } \\
\text { ER= } \\
2.96 \\
\end{array}$ \\
\hline $\begin{array}{l}\text { DD/MM } \\
\text { MYYY }\end{array}$ & & $\mathrm{mm}$ & $\mathrm{mm}$ & $\begin{array}{l}\mathrm{m}^{2} \\
\mathrm{~m}^{-2}\end{array}$ & $\begin{array}{l}\mathrm{m}^{2} \\
\mathrm{~m}^{-2}\end{array}$ & $\begin{array}{l}\mathrm{kg} \\
\mathrm{m}^{-2} \\
\end{array}$ & $\begin{array}{l}m^{2} \\
m^{-2} \\
\end{array}$ & $\mathrm{~m}$ & $\begin{array}{l}\mathrm{m}^{2} \\
\mathrm{~m}^{-2}\end{array}$ & $\begin{array}{l}\mathrm{m}^{2} \\
\mathrm{~m}^{-2} \\
\end{array}$ & $\mathrm{~mm}$ & $\begin{array}{l}\mathrm{Mg} \\
\mathrm{Mg}^{-1} \\
\end{array}$ & deg & $\begin{array}{l}\mathrm{kg} \\
\mathrm{m}^{-2} \\
\end{array}$ & $\%$ & $\begin{array}{l}\mathrm{kg} \\
\mathrm{m}^{-2} \\
\end{array}$ & $\begin{array}{l}\% \text { of } \\
\text { total }\end{array}$ & $\begin{array}{l}\mathrm{kg} \\
\mathrm{m}^{-2} \\
\end{array}$ & $\begin{array}{l}\% \text { of } \\
\text { total }\end{array}$ & $\mathrm{cm}$ & $\begin{array}{l}\mathrm{kg} \\
\mathrm{m}^{-2} \\
\end{array}$ & $\begin{array}{l}\mathrm{kg} \\
\mathrm{m}^{-2} \\
\end{array}$ \\
\hline \multicolumn{23}{|c|}{ site A - $2000-2009$} \\
\hline 09/05/2001 & 0 & 4.00 & 25.00 & 0 & 0 & 0 & 0 & 0 & 0 & 0 & 0 & 0 & 70 & 2.1 & 5.9 & 0.4 & 18 & 1.7 & 82 & 0.45 & 0.01 & 0.12 \\
\hline 09/05/2002 & 0 & 4.00 & 25.00 & 0 & 0 & 0 & 0 & 0 & 0 & 0 & 0 & 0 & 57 & 8.4 & 3.5 & 4.3 & 51 & 4.1 & 49 & 0.72 & 0.10 & 0.27 \\
\hline 10/05/2002 & 0 & 4.00 & 25.00 & 0 & 0 & 0 & 0 & 0 & 0 & 0 & 0 & 0 & 83 & 12.6 & 1.7 & 0.3 & 2 & 12.3 & 98 & 3.53 & 0.01 & 0.80 \\
\hline 03/05/2003 & 0 & 4.00 & 25.00 & 0 & 0 & 0 & 0.25 & 0 & 0 & 0 & 0.3 & 0.05 & 250 & 0.8 & 25.1 & 0.4 & 53 & 0.4 & 47 & 0.06 & 0.01 & 0.02 \\
\hline 09/06/2003 & 32 & 1.53 & 6.66 & 0.62 & 0.25 & 0.01 & 0 & 0.38 & 0.03 & 0.25 & 110 & 0 & 235 & 0.3 & 75.2 & 0.2 & 50 & 0.2 & 50 & 0.00 & 0.00 & 0.01 \\
\hline $11 / 06 / 2003$ & 34 & 1.50 & 6.66 & 1.00 & 1.00 & 0.03 & 0 & 0.41 & 0.03 & 0.31 & 4.5 & 0 & 240 & 0.0 & 60.2 & 0.0 & 100 & 0.0 & 0 & 0.00 & 0.00 & 0.00 \\
\hline $29 / 04 / 2004$ & 2 & 4.00 & 25.00 & 0 & 0 & 0 & 0.25 & 0 & 0 & 0 & 0 & 0 & 100 & 0.0 & 0.2 & 0.0 & 23 & 0.0 & 77 & 0.01 & 0.00 & 0.00 \\
\hline $30 / 04 / 2004$ & 3 & 3.98 & 24.91 & 0 & 0 & 0 & 0.25 & 0 & 0 & 0 & 0 & 0 & 85 & 4.0 & 1.2 & 1.6 & 39 & 2.5 & 61 & 0.54 & 0.03 & 0.15 \\
\hline 09/05/2006 & 0 & 4.00 & 25.00 & 0 & 0 & 0 & 0 & 0 & 0 & 0 & 0 & 0 & 80 & 3.0 & 2.5 & 0.1 & 5 & 2.8 & 95 & 0.79 & 0.00 & 0.17 \\
\hline 19/04/2007 & 4 & 4.00 & 25.00 & 0 & 0 & 0 & 0.25 & 0 & 0 & 0 & 1.1 & 0 & 250 & 0.0 & 35.9 & 0.0 & 56 & 0.0 & 45 & 0.00 & 0.00 & 0.00 \\
\hline 20/04/2007 & 0 & 4.00 & 25.00 & 0 & 0 & 0 & 0 & 0 & 0 & 0 & 0.4 & 0.05 & 307 & 3.6 & 2.4 & 1.8 & 50 & 1.8 & 50 & 0.71 & 0.04 & 0.11 \\
\hline 22/04/2008 & 0 & 4.00 & 25.00 & 0 & 0 & 0 & 0 & 0 & 0 & 0 & 0 & 0 & 80 & 7.6 & 2.2 & 0.3 & 4 & 7.3 & 96 & 0.21 & 0.01 & 0.43 \\
\hline $23 / 04 / 2008$ & 1 & 1.50 & 9.90 & 1.00 & 1.00 & 1.98 & 0 & 0 & 0 & 0 & 0 & 0 & 93 & 0.0 & 89.8 & 0.0 & 100 & 0.0 & 0 & 0.00 & 0.00 & 0.00 \\
\hline 25/04/2009 & 1 & 4.00 & 25.00 & 0 & 0 & 0 & 0 & 0 & 0 & 0 & 0 & 0 & 97 & 4.1 & 0.5 & 0.0 & 1 & 4.0 & 99 & 1.16 & 0.00 & 0.23 \\
\hline 27/04/2009 & 0 & 4.00 & 25.00 & 0 & 0 & 0 & 0 & 0 & 0 & 0 & 0 & 0 & 195 & 2.4 & 18.2 & 1.4 & 58 & 1.0 & 42 & 0.01 & 0.03 & 0.06 \\
\hline 28/04/2009 & 1 & 1.50 & 6.57 & 1.00 & 1.00 & 0.14 & 0 & 0 & 0 & 0 & 0.4 & 0 & 80 & 0.0 & 72.1 & 0.0 & 100 & 0.0 & 0 & 0.00 & 0.00 & 0.00 \\
\hline \multirow[t]{2}{*}{ TOTAL } & & & & & & & & & & & & & & 48.9 & & 10.8 & $22^{\mathrm{e}}$ & 38.1 & $78^{e}$ & & 0.226 & 2.369 \\
\hline & & & & & & & & & & & & & & & & & & & & & \multicolumn{2}{|c|}{$2.595^{f}$} \\
\hline \multicolumn{2}{|c|}{ site B - 2000 - 2009} & & & & & & & & & & & & & & & & & & & & & \\
\hline 04/06/2006 & 24 & 2.85 & 13.99 & 0.53 & 0.21 & 0.64 & 0 & 0.13 & 0.00 & 0.04 & 72.5 & 0 & 310 & 0.4 & 97.7 & 0.3 & 73 & 0.1 & 27 & 0.00 & 0.01 & 0.01 \\
\hline $11 / 05 / 2007$ & 19 & 2.88 & 20.04 & 0.38 & 0.39 & 0.17 & 0 & 0.09 & 0.00 & 0.02 & 2.7 & 0.02 & 250 & 0.0 & 75.0 & 0.0 & 80 & 0.0 & 20 & 0.00 & 0.00 & 0.00 \\
\hline 17/05/2007 & 25 & 1.85 & 14.15 & 0.40 & 0.16 & 0.64 & 0 & 0.13 & 0.00 & 0.04 & 14.6 & 0 & 300 & 0.4 & 89.9 & 0.3 & 75 & 0.1 & 25 & 0.00 & 0.01 & 0.01 \\
\hline 15/05/2009 & 25 & 3.49 & 21.53 & 0.40 & 0.16 & 0.64 & 0 & 0.14 & 0.00 & 0.05 & 0 & 0 & 90 & 0.0 & 27.5 & 0.0 & 73 & 0.0 & 27 & 0.00 & 0.00 & 0.00 \\
\hline 22/05/2009 & 32 & 2.46 & 16.99 & 0.40 & 0.56 & 0.61 & 0 & 0.22 & 0.01 & 0.10 & 21.6 & 0 & 260 & 0.0 & 72.9 & 0.0 & 80 & 0.0 & 20 & 0.00 & 0.00 & 0.00 \\
\hline $26 / 05 / 2009$ & 36 & 1.90 & 14.69 & 0.40 & 0.5 & 0.60 & 0 & 0.28 & 0.01 & 0.14 & 4.1 & 0 & 250 & 0.1 & 51.3 & 0.1 & 79 & 0.0 & 21 & 0.00 & 0.00 & 0.00 \\
\hline 28/05/2009 & 38 & 1.87 & 14.56 & 0.40 & 0.49 & 0.46 & 0 & 0.31 & 0.02 & 0.17 & 6.1 & 0 & 300 & 0.0 & 119.4 & 0.0 & 75 & 0.0 & 25 & 0.00 & 0.00 & 0.00 \\
\hline TOTAL & & & & & & & & & & & & & & & & & & & & & & 0.031 \\
\hline
\end{tabular}

day after last tillage operation

b cumulative depth of precipitation since last tillage or erosion event

thickness of new pure sand horizon after this even

cumulative depth of precipitation since last tillage or erosion event
relevant cumulated hourly surface water content during erosion event 
In years with more than one erosion event and without tillage random and oriented roughness decline was considered. As a consequence of the decline also less erosive winds were able to initiate erosion at site $A$. This was mostly the case when random roughness and ridge height were $<2 \mathrm{~mm}$ and $<10 \mathrm{~mm}$, respectively. The crust caused by surface fixation by cattle slurry $\left(5 \mathrm{~m}^{3} \mathrm{ha}^{-1}\right)$ was sufficient protective against wind erosion and no erosion was modeled. In 2003 the slurry crust was destroyed by heavy rainfall of $27.1 \mathrm{~mm}$ on 08/06/2003. Thus, the soil surface was susceptible to wind erosion and erosive winds could erode soil material on two days. As a consequence of $110 \mathrm{~mm}$ of precipitation since the last tillage operation, random and oriented roughness decreased to a minimum, so that erosion could take place even though wind speeds were relatively low. $0.32 \mathrm{~kg} \mathrm{~m}^{-2}$ of total soil loss through westerly winds was modeled at site A. In 2004 the slurry crust was destroyed again, but a new slurry layer was applied immediately. Therefore, more slurry was utilized $\left(15 \mathrm{~m}^{3} \mathrm{ha}^{-1}\right)$ in 2005 , which could resist heavy rainfall of $29.3 \mathrm{~mm}$ without losing the crust.

Precipitation was typically related to westerly winds reducing susceptibility to erosion by increased surface water contents. Mostly, precipitation sums after last tillage operations were quite low $(<10 \mathrm{~mm}$ ); thus, on 15 out of 16 days no surface crusts by precipitation developed. At five events of westerly winds a total soil loss of $4.74 \mathrm{~kg} \mathrm{~m}^{-2}$ occurred at site A, whereas at easterly wind events $41.81 \mathrm{~kg} \mathrm{~m}^{-2}$ were modeled. Three erosive days were characterized by pure sand layers which developed on the surface by high suspension loss, i.e. especially loss of parts of the fine sand and silt fractions (see Table 6). In each case model results of the following erosive day stated that these sand layers were not completely eroded; indicating that the underlying fine soil material was not susceptible to erosion.

At site $B$, featuring closer wind barriers to the northeast, the average total soil losses were much smaller and the variability of the SWEEP grid cells was higher. Most of the erosive days coincided with a crusted surface or growing crops. 7 erosive days were modeled, resulting in $1.0 \mathrm{~kg} \mathrm{~m}^{-2}$ of total soil loss and a saltation/suspension ratio of 75:25. This total soil loss of ten years corresponds to the measured topsoil loss $\left(2.4 \mathrm{~kg} \mathrm{~m}^{-2}\right)$. The maximum total soil loss of a single event was $0.4 \mathrm{~kg} \mathrm{~m}^{-2}$, eroded by northwesterly winds. All erosive days showed average loss in both creep/saltation and suspension. Some events were characterized by very small deposition at the western part of the monitoring site.

\subsection{Comparing SOC losses from measurement, balances and modeling results}

At site A a SOC stock decrease of $2.44 \mathrm{~kg} \mathrm{~m}^{-2}$ was measured in the topsoil within the period 1999-2009. The total conventional SOC balance method resulted in an increase of $0.15 \mathrm{~kg}$ $\mathrm{m}^{-2}$. Based on the wind erosion modeling results SOC loss by creep/saltation was quantified to $0.23 \mathrm{~kg} \mathrm{~m}^{-2}$ for all 16 erosion events of the test period. Considering reduced SOC contents 
494

495

496

497

498

499

500

501

502

503

504

505

506

507

508

509

510

511

in the uppermost layer after each erosion event the remaining sum of $2.37 \mathrm{~kg} \mathrm{~m}^{-2}$ was estimated to be transported by suspension with an ER of 2.96. Highest SOC loss by creep/saltation was on 09/05/2002 $\left(0.10 \mathrm{~kg} \mathrm{~m}^{-2}\right)$ and by suspension on 10/05/2002 (0.80 kg $\mathrm{m}^{-2}$ ). SOC losses at site B were low. Developing ER's for site B from the present data of very few soil loss would feature a large uncertainty. Therefore, the same ERs as at site A were used, as it is geographically very close. Using these ERs, $0.031 \mathrm{~kg} \mathrm{~m}^{-2}$ of SOC was eroded by creep/saltation and $0.031 \mathrm{~kg} \mathrm{~m}^{-2}$ by suspension in the test period.

\subsection{Modeling variations}

The calculated soil losses using variations of sensitive parameters (Table 9) show that varying wind speed had the largest effect on the modeling results of site $A(-44 \%$ and $+62 \%)$. A roughness variation impacted the total soil loss also significantly $(-33 \%$ and $+11 \%)$ while a longer dry-up time had a negligible effect because most erosion events were days without rain close to the erosive hours (15 of 16$)$.

Table 9: Calculated modeling soil losses using wind speed, surface roughness and surface dry-up variations for the test period 1999-2009 of the monitoring site A.

\begin{tabular}{|c|c|c|c|c|c|c|c|}
\hline \multirow[t]{2}{*}{ event no. } & \multirow[t]{2}{*}{ date } & \multirow{2}{*}{$\begin{array}{l}\text { without } \\
\text { variation }\end{array}$} & \multicolumn{2}{|c|}{ Wind speed variation } & \multicolumn{2}{|c|}{ Roughness variation } & \multirow{2}{*}{$\begin{array}{l}\text { Surface water drying } \\
\text { up } \\
\text { after } 4 \text { hours instead of } \\
2 \text { hours }\end{array}$} \\
\hline & & & $-5 \%$ & $+5 \%$ & $\begin{array}{l}+20 \text { to } \\
+25 \%\end{array}$ & $\begin{array}{c}-20 \text { to }- \\
25 \%\end{array}$ & \\
\hline & & $\mathrm{kg} \mathrm{m}^{-2}$ & $\mathrm{~kg} \mathrm{~m}^{-2}$ & $\mathrm{~kg} \mathrm{~m}^{-2}$ & $\mathrm{~kg} \mathrm{~m}^{-2}$ & $\mathrm{~kg} \mathrm{~m}^{-2}$ & $\mathrm{~kg} \mathrm{~m}^{-2}$ \\
\hline 1 & $09 / 05 / 2001$ & 2.1 & 0.4 & 4.4 & 0.0 & 3.1 & 2.1 \\
\hline 2 & 09/05/2002 & 8.4 & 3.4 & 15.3 & 0.1 & 8.0 & 8.4 \\
\hline 3 & $10 / 05 / 2002$ & 12.6 & 8.2 & 18.1 & 12.3 & 12.8 & 12.6 \\
\hline 4 & 03/05/2003 & 0.8 & 0.6 & 1.0 & 0.3 & 1.6 & 0 \\
\hline 5 & 09/06/2003 & 0.3 & 0.2 & 0.4 & 0.3 & 0.4 & 0.3 \\
\hline 6 & $11 / 06 / 2003$ & 0.0 & 0.0 & 0.0 & 0.0 & 0.0 & 0.0 \\
\hline 7 & $29 / 04 / 2004$ & 0.0 & 0.0 & 0.0 & 0.0 & 0.3 & 0.0 \\
\hline 8 & $30 / 04 / 2004$ & 4.0 & 3.0 & 5.2 & 2.9 & 5.1 & 4.0 \\
\hline 9 & 09/05/2006 & 3.0 & 1.3 & 5.3 & 2.2 & 3.2 & 3.0 \\
\hline 10 & $19 / 04 / 2007$ & 0.0 & 0.0 & 0.0 & 0.0 & 0.3 & 0.0 \\
\hline 11 & $20 / 04 / 2007$ & 3.6 & 0.8 & 10.0 & 2.7 & 4.1 & 3.6 \\
\hline 12 & $22 / 04 / 2008$ & 7.6 & 5.2 & 10.3 & 6.8 & 7.8 & 7.6 \\
\hline 13 & $23 / 04 / 2008$ & 0.0 & 0.0 & 0.0 & 0.0 & 0.0 & 0.0 \\
\hline 14 & $25 / 04 / 2009$ & 4.1 & 2.5 & 6.0 & 3.7 & 4.2 & 4.1 \\
\hline 15 & $27 / 04 / 2009$ & 2.4 & 1.7 & 3.2 & 1.5 & 3.7 & 2.4 \\
\hline 16 & 28/04/2009 & 0.0 & 0.0 & 0.0 & 0.0 & 0.0 & 0.0 \\
\hline & SUM & 48.9 & 27.3 & 79.3 & 32.7 & 54.5 & 48.2 \\
\hline & Differences in \% & - & 44 & 62 & 33 & 11 & 2 \\
\hline
\end{tabular}




\section{Discussion}

The comparison of two study sites influenced by wind erosion to a different extent showed a very good agreement between measured and modeled topsoil loss. Within the ten-yearperiod the measured topsoil loss at site A corresponds almost exactly to the modeled soil loss. For the reference site $B$, the modeled very small soil and SOC losses are as well in accordance with the topsoil measurements.

The absolute loss of $49 \mathrm{~kg} \mathrm{~m}^{-2}$ over ten years $\left(4.9 \mathrm{~kg} \mathrm{~m}^{-2} \mathrm{a}^{-1}\right)$ at site $A$ can be considered as very high but not unusual; Zhang et al. (2017) worked as well with SWEEP and determined 4-5 $\mathrm{kg} \mathrm{m}^{-2}$ per year for an entire field.

The maximum single-event soil loss of $12.64 \mathrm{~kg} \mathrm{~m}^{-2}$ was caused by dry easterly winds, which is comparable to other measured very strong wind erosion events; e.g. $17 \mathrm{~kg} \mathrm{~m}^{-2}$ in German Lower Saxony (Schäfer and Neemann, 1990) at sites with similar soil and environmental conditions. Not focusing on the center part but on the entire field Bach (2008) modeled with another process-based model (TEAM, Gregory et al., 2004) a total soil loss of $13.08 \mathrm{~kg} \mathrm{~m}^{-2}$ for four days in March 1969 at the same area as in this study (site A).

The relatively long field length to the east, in main wind direction, explains proportions of $99 \%$ suspension in some erosion events at the monitoring site in this study. After a field length of approx. $100 \mathrm{~m}$ the maximum transport capacity of saltation is reached - erosion and deposition are in equilibrium - whereas suspension transport is constantly increasing and never reaches saturation (Hagen et al., 1995).

The results of Funk et al. (2004) are supporting the modeling results of this study. For their validation of the SWEEP model in Germany the authors reported an excellent agreement between measured and simulated soil loss, especially for large erosion events. Model results confirm that wind erosion is much higher at site A compared to site $B$. Without erosion control by cattle slurry and solid manure (cf. Funk \& Riksen, 2007; Riksen et al., 2003) soil and SOC loss would have been extraordinary high at site $A$.

The strong decline of the topsoil mass at site A over ten years shows the erosion impact, whereas soil mass at site $B$ (less affected by erosion) remained nearly constant. This relation is in accordance with the literature (cf. Ellert and Bettany, 1995; Kibblewhite et al., 2012). Another indication for the wind erosion impact is the declined fine sand fraction at site A from 1999 to 2009 (cf. Li et al., 2009). Particles of this size are preferably transported in wind erosion events (Hagen et al., 1995).

The analytical and modeling results bear also given uncertainties. This was shown e.g. in Table 6 and Table 9. In the recent literature for SWEEP the model was evaluated to 
overestimate the threshold friction velocity, which is necessary to initiate wind erosion (Zhang et al., 2017; Pi et al., 2014; Feng \& Sharratt, 2007, 2009). This is especially important for smaller erosion events. However, most of the soil and SOC loss reported in this study was caused by large erosion events of high wind speeds. Smaller events could be affected; this might be the reason for the difference of $1.4 \mathrm{~kg} \mathrm{~m}^{-2}$ between measured topsoil loss and modeled loss at site B. Once SWEEP detected erosion it overpredicted the modeled soil loss in the Columbia Plateau (USA) by $200-700 \mathrm{~kg} \mathrm{ha}^{-1}$ (Feng \& Sharratt, 2007) which translates to $0.02-0.07 \mathrm{~kg} \mathrm{~m}^{-2}$ and is therefore negligible for this study, as $48.9 \mathrm{~kg} \mathrm{~m}^{-2}$ were modeled and its aim was to designate the main part of the measured topsoil SOC loss to wind erosion.

\subsection{SOC loss by wind erosion}

The SOC loss determined by measurements and modeling at site A corresponds to the high soil loss. The SOC loss of $2.44 \mathrm{~kg} \mathrm{~m}^{-2}$ in ten years is an important degradation factor reducing soil fertility at the study site.

The determination of a considerable change of SOC $(10-15 \%)$ in soils requires an adequate sample size. This size was determined as $n=16$ (Garten and Wullschleger, 1999). Considering the 18 sampling points in the BDF program, each containing two cores, this size is clearly reached (cf. Nerger et al., 2016). Using standardized sampling and laboratory methods all three composite samples of site A showed significantly declined SOC stocks.

To assign the estimated SOC losses to wind erosion other possible SOC losses have to be excluded. Water and tillage erosion were not relevant (cf. sections 1 and 2.4.1). Tillage depth changed 2003 at site $A$ from 30 to $25 \mathrm{~cm}$ as documented in the management data base. Thus, a possible thinning effect from subsoil material intermixed with topsoil material can be excluded.

SOC losses were considered separately by using different ER for the saltation and suspension part of the soil losses. ERs can vary in space and time as indicated by Webb et al. (2012) or in consecutive measurements as well by sampler type (Funk, 1995). Nevertheless, over a long-term period these variations are minimized (Figure 4).

ERs for saltation transport were derived from wind tunnel experiments (Bach, 2008) with soil material from Site A. The chosen ER of 0.98 for saltation fits very good to the function derived from data of several authors (Fig. 4). The same applies to the suspension ER found in this study (2.96). It is very similar to the ER of 3.02 found by Sterk et al. (1996) and the ERs of 3.02 and 3.63 of Webb et al. (2012) and can therefore be considered as a reasonable value for SOC loss mainly by suspension. 


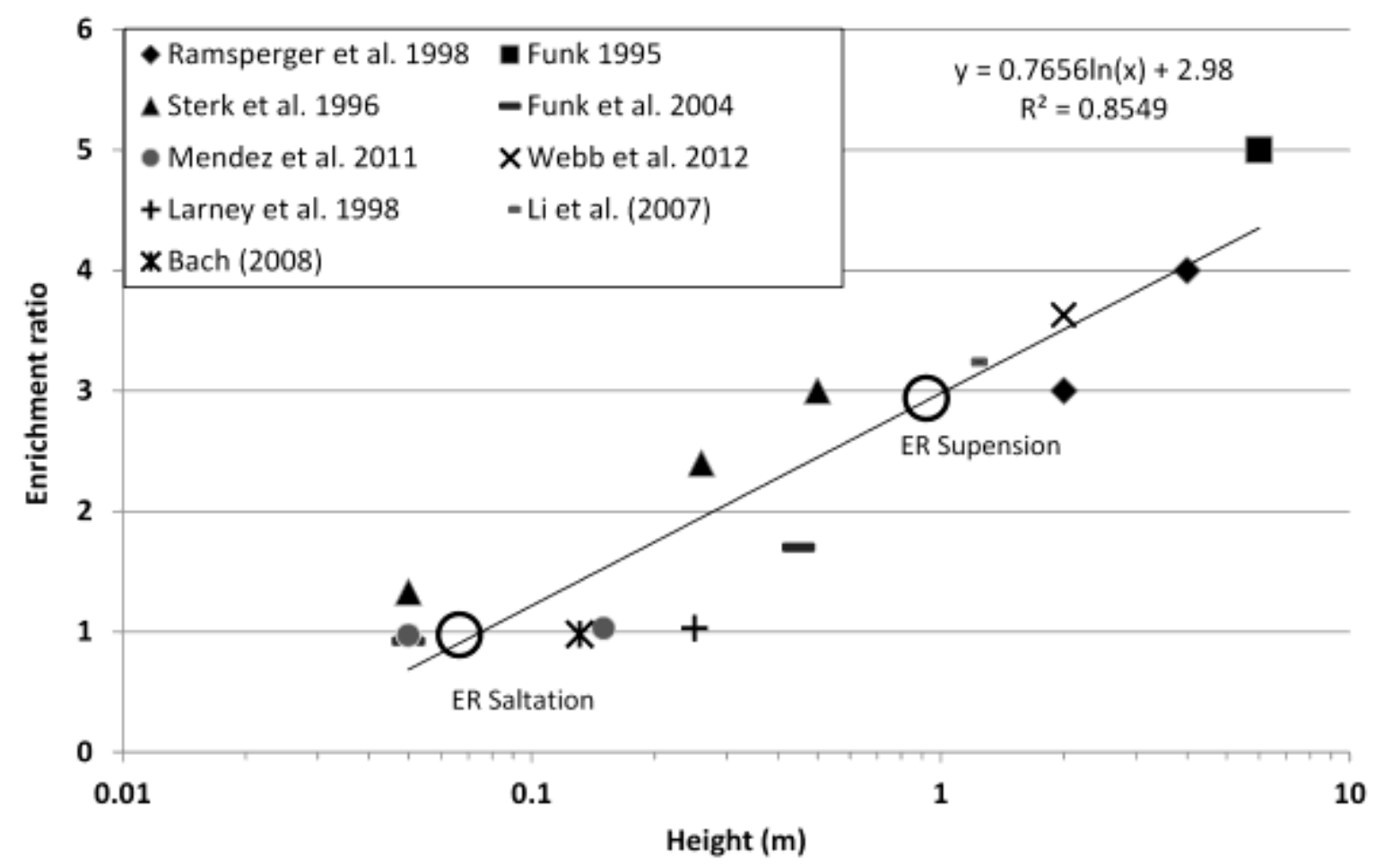

586

587

588

589

590

591

592

593

594

595

596

597

598

599

600

601

602

603

604

605

606

607

Figure 4: Comparison of the enrichment ratios found in the present study with those of the literature

\subsection{Significance and limitations of the study approach}

The results are of relevance for evaluating long-term soil and SOC losses by wind erosion. Wind erosion measurements are not feasible for such long-term periods, therefore, approaches using modeling (Post et al. 2001), long-term soil monitoring (Lal, 2005) or soil sampling and modeling (Chappell et al., 2013; Chappell \& Viscarra Rossel, 2013) may be more appropriate. The selected approach to combine topsoil measurements, detailed management data and process-based modeling allows to quantify the impact of wind erosion as land degradation process. To date there is no similar approach quantifying these longterm impacts of wind erosion. The presented approach is limited to sites without noteworthy SOC changes due to other processes such as water erosion and without presence of a thinning effect.

Adequate region-specific and characterization studies are necessary if the SWEEP model is applied without direct measurements of wind erosion. The estimation of all main input parameters in the model setup is based on field observations or measurements of the study site or on adequate validation studies (Funk et al., 2004; Hagen, 1995; Bach, 2008; references in Table 3). This covers the most sensitive parameters mentioned in Hagen et al. (1999) and Feng \& Sharratt (2005) and enables to conclude that the study reconstructs reasonable erosion events and SOC loss even without direct erosion measurements in 
sandy soils of Northern Germany. However, the exact results bear also an uncertainty. This was shown in Table 6 and chapter 3.5. Especially wind sped variations may have a large impact on the result, therefore, this study benefits from the used official and quality-proved 10-minute wind speed data set. Although a given uncertainty remains, the importance of the presented study lies more in the reliable designation of the main part of the measured SOC losses to wind erosion.

\section{Conclusions}

The applied approach, combining high-quality long-term monitoring data of soil and farming management as well as high-resolution wind speed data with a process-based wind erosion model, was successful. The measured SOC losses could be designated to wind erosion and confirms the impact of this soil degradation in arable sandy soils of Northern Germany. Although based on measured data it is an indirect estimation approach as wind erosion was not measured directly. However, it seems to be an adequate method to estimate wind erosion induced soil and SOC loss, especially for long-term periods (decades) where continuous erosion measurements are not possible

The key data is the BD-SH SMN using consistent sampling and laboratory methods of standardized monitoring routines allowing the determination of uncertainties and thus significant changes in time for long-term periods (Nerger et al., 2016). Although the results are limited to the study sites in Northern Germany, the presented procedure could be interesting for similar environments when long-term soil monitoring data are available and non-Aeolian causes for SOC loss can be excluded. The application of ER factors for SOC losses by saltation and suspension could improve carbon accounting systems and wind erosion models, following the recommendation of Webb et al. (2012).

\section{Acknowledgments}

We would like to thank both the Department Geology and Soil, Soil Conservation of the State Agency of Agriculture, Environment and Rural Areas of the Federal State Schleswig-Holstein (LLUR) and the Ministry of Energy, Agriculture, the Environment and Rural Areas of the Federal State Schleswig-Holstein (MELUR) for the financial support (LLUR grant number: 4121-3-2007-440F), the good cooperation and the data supply. We would also like to thank Larry E. Wagner from the Wind Erosion Research Unit (WERU) of the United States Department of Agriculture (USDA) for his good advice on some technical details of the SWEEP model. 


\section{References}

647

648

Ad-Hoc-AG Boden, 2005. Bodenkundliche Kartieranleitung. 5th edition, 438 pp., Hannover, 649 Germany.

650

651

Armbrust, D.V., Lyles, L., 1985. Equivalent wind erosion protection from selected growing 652 crops. Agron. J. 77, 703-707.

653

654

655

Bach, M., 2008. Äolische Stofftransporte in Agrarlandschaften - Experimentelle

656 Untersuchungen und räumliche Modellierung von Bodenerosionsprozessen durch Wind.

Ph.D. Thesis, 129 pp. University of Kiel, Germany.

657

658

Barth, N., Brandtner, W., Cordsen, E., Dann, T., Emmerich, K.-H., Feldhaus, D., Kleefisch, 659 B., Schilling, B., Utermann, J., 2001. Boden-Dauerbeobachtung - Einrichtung und Betrieb 660 von Boden-Dauerbeobachtungsflächen, in: Rosenkranz, D., Bachmann, G., König, W., Einsele, G. (Ed.): Bodenschutz. Kennziffer 9152, 32. Lfg. XI/00, Erich Schmidt Verlag, Berlin, Germany, $127 \mathrm{pp}$.

663

Blanco-Canqui, H., Lal, R., 2008. Principles of Soil Conservation and Management. Berlin: Springer Verlag, 620 pp.

666

667

Blume, H.-P., Leinweber, P., 2004. Plaggen Soils: Landscape History, Properties and 668 Classification. J. Plant Nutr. Soil Sci. 167, 319-327.

669

Blume, H.-P., Brümmer, G., Schwertmann, U., Horn, R., Kögel-Knabner, I., Stahr, K., Auerswald, K., Beyer, L., Hartmann, A., Litz, N., Scheinost, A., Stanjek, H., Welp, G., 2002. Scheffer / Schachtschabel. - Lehrbuch der Bodenkunde, 15. Auflage. Spektrum Akademischer Verlag, Heidelberg, Germany, 593 pp.

674

Buschiazzo, D., Funk, R., 2015. Wind erosion of agricultural soils and the carbon cycle, in: Banwart, S. A., Noellemeyer, E., Milne, E. (Eds), Soil carbon: science, management and policy for multiple benefits. CABI, Wallingford pp. 161-168.

Chappell, A., Baldock, J. A., 2016. Wind erosion reduces soil organic carbon sequestration 680 falsely indicating ineffective management practices. Aeolian Res., 22, 107-116. 
682

683

684

685

686

687

688

689

690

691

692

693

694

695

696

697

698

699

700

701

702

703

704

705

706

707

708

709

710

711

712

713

714

715

716

717

Chappell, A., Viscarra Rossel, R.A., 2013. The importance of sampling support for explaining change in soil organic carbon. Geoderma, 193, 323-325.

Chappell, A., Webb, N.P., Butler, H.J., Strong, C.L., McTainsh, G. H., Leys, J.F., Viscarra Rossel, R.A., 2013. Soil organic carbon dust emission: an omitted global source of atmospheric CO2. Global Change Biol., 19(10), 3238-3244.

de Rouw, A., Rajot, J.-L., 2004a. Nutrient availability and pearl millet production in Sahelian farming systems based on manuring or fallowing. Agric. Ecosyst. Environ. 104, 249-262.

de Rouw, A., Rajot, J.-L., 2004b. Soil organic matter, surface crusting and erosion in Sahelian farming systems based on manuring or fallowing. Agric. Ecosyst. Environ. 104, 263-276.

Duttmann, R., Bach, M., 2006. Long-Term Wind Erosion and its Impact on Soil Heterogeneity in Sandur Plain Landscapes in Northern Germany. Adv. Geoecol. 38, 309-319.

Duttmann, R., Hassenpflug, W., Bach, M., Lungershausen, U., Frank, J.H., 2011. Winderosion in Schleswig-Holstein, in: Landesamt für Landwirtschaft, Umwelt und ländliche Räume des Landes Schleswig-Holstein (LLUR) (Ed.). Series LLUR SH Geologie und Boden; 15. Flintbek, Germany.

DWD, 2010. Windkarten und Winddaten für Deutschland. Bezugsraum $1981-2000$.

Ellert, B. H., Bettany, J. R., 1995. Calculation of Organic Matter and Nutrients Stored in Soils under Contrasting Management Regimes. Can. J. Soil Sci. 75, 529-538.

EURACHEM/CITAC, 2000. Quantifying uncertainty in analytical measurement, 2nd edition.

FAO \& ITPS, 2015. Status of the World's Soil Resources (SWSR). Food and Agriculture Organization of the United Nations and Intergovernmental Technical Panel on Soils, Rome, Italy.

Farres, P., 1978. The Role of Time and Aggregate Size in the Crusting Process. Earth Surf. Process. 3, 243-254. 
Feng, G., Sharratt, B.S., 2005. Sensitivity analysis of soil and PM10 loss in WEPS using LHS-OAT method. Transactions of the ASAE 48(4): 1409-1420.

720

Feng, G., Sharratt, B., 2007. Validation of WEPS for soil and PM10 loss from agricultural fields within the Columbia Plateau of the United States. Earth Surf. Process. and Landforms, 32(5), 743-753.

724

Feng, G., Sharratt, B., 2009. Evaluation of the SWEEP model during high winds on the Columbia Plateau. Earth Surface Processes and Landforms 34:1461-1468. Earth Surf. Process. 34, 1461-1468.

Fryrear, D.W., 1985. Soil cover and wind erosion. Trans. ASAE 28, 781-784.

730

Fryrear, D.W., Ali Saleh, J.D. Bilbro, H.M. Schomberg, J.E. Stout, Zobeck T.M., 1998. Revised Wind Erosion Equation (RWEQ). Wind Erosion and Water Conservation Research Unit, USDA-ARS, Southern Plains Area Cropping Systems Research Laboratory. Technical Bulletin No. 1.

Funk, R., 1995. Quantifizierung der Winderosion auf einem Sandstandort Brandenburgs unter besonderer Berücksichtigung der Vegetationswirkung. Ph.D. Thesis, in: ZALF-Bericht No. 16, Müncheberg, Germany.

739

Funk, R., Li, Y., Hoffmann, C., Reiche, M., Zhang, Z., Li, J., Sommer, M., 2012. Using 137Cs to estimate wind erosion and dust deposition on grassland in Inner Mongolia-selection of a reference site and description of the temporal variability. Plant Soil, 351 (1-2), 293-307.

Funk, R., Skidmore, E.L., Hagen, L., 2004. Comparison of wind erosion measurements in Germany with simulated soil losses by WEPS. Environ. Modell. Softw. 19, 177-183.

Funk, R., Riksen, M., 2007. Measures to reduce wind erosion and related dust emissions, in: DustConf 2007 'How to improve air quality': International Conference in Maastricht, The Netherlands, 23-24 April 2007: 1-11; Maastricht (Maastricht Exhibition and Congress Centre). dust emission from tillage operations on agricultural soils. Earth Surf. Processes Landforms. 33 (12), 1851-1863. 
Garten C.T., Wullschleger, S.D., 1999. Soil carbon inventories under a bioenergy crop

(Switchgrass): measurement limitations. J. Environ. Qual., 28, 1359-1365.

758

759

Giani, L., Makowsky, L., Mueller, K., 2014. Plaggic Anthrosol: Soil of the Year 2013 in

Germany: An overview on its formation, distribution, classification, soil function and threats. Journal of Plant Nutrition and Soil Science, 177(3), 320-329.

762

763

Gregory, J.M., Wilson, G.R., Singh, U.B., Darwish, M.M., 2004. TEAM: integrated, process764 based wind-erosion model. Environ. Modell. Softw. 19, 205-215.

765

Goossens D., 2004. Net loss and transport of organic matter during wind erosion on loamy sandy soil. in: Wind Erosion and Dust Dynamics: Observations, Simulations, Modelling,

Goossens, D., Gross, J., 2002. Similarities and dissimilarities between the dynamics of sand and dust during wind erosion of loamy sandy soil. Catena 47, 269-289.

Hagen, L. J., 1991. A wind erosion prediction system to meet user needs. J. Soil Water Conserv. 46(2), 106-111.

Hagen, L.J., 2004. Evaluation of the wind erosion prediction system (WEPS) erosion submodel on cropland fields. Environ. Modell. Softw. 2, 171-176.

778

Hagen, L.J., 2008. Updating soil surface conditions during wind erosion events using the 780 Wind Erosion Prediction System (WEPS). Trans. ASABE 51 (1), 129-137.

Hagen, L.J., Skidmore, E.L., Miller, P.L., Kipp, J.E., 1981. Simulation of the effect of wind barriers on airflow. Trans. Amer. Soc. Agric. Engin. 24(4), 1002-1008.

Hagen, L. J., Wagner, L. E., Skidmore, E. L., 1999. Analytical solutions and sensitivity analysis for sediment transport in WEPS. Trans. ASAE 42(6): 1715-1721. Schomberg, H.H., Retta, A., Armbrust, D.V., Zobeck, T.M., Unger, P.W., Ding, D., Elminyawi, 
WEPP/WEPS Symposium, August 9-11, Des Moines, IA, Soil and Water Conservation Society, Ankeny, IA, USA.

Hassenpflug, W., 1998. Bodenerosion durch Wind, in: Richter, G. (Ed.): Bodenerosion. Analyse und Bilanz eines Umweltproblems. Richter, G. (Ed), Darmstadt, Germany, pp. 69-82

IUSS Working Group WRB, 2006. World reference base for soil resources 2006. $2^{\text {nd }}$ edition. World Soil Resources Reports No. 103. FAO, Rome.

Kibblewhite, M.G., Miko, L., Montanarella, L., 2012. Legal frameworks for soil protection: current development and technical information requirements. Curr. Opin. Environ. Sustain. 4(5), 573-577.

Kolbe, H., 2010. Site-adjusted organic matter-balance method for use in arable farming systems. J. Plant Nutr. Soil Sci. 173, 678-691.

Lal, R., 2003. Soil erosion and the global carbon budget. Environ. Int. 29, 437-450.

Lal, R., 2005. Soil erosion and carbon dynamics. Soil Till Res. 81, 137-142.

Lal, R., 2014. Principles and Practices of Soil Resource Conservation, in: eLS. John Wiley \& Sons Ltd, Chichester. http://www.els.net [doi: 10.1002/9780470015902.a0003295.pub2]

Larney, F.J., Bullock, M.S., Janzen, H.H., Ellert, B.H., Olson, E.C., 1998. Wind erosion effects on nutrient redistribution and soil productivity. J. Soil Water Conserv. 53, 133-140.

Li, J.R., Okin, G.S., Alvarez, L., Epstein, H., 2007. Quantitative effects of vegetation cover on wind erosion and soil nutrient loss in a desert grassland of southern New Mexico, USA. Biogeochemistry 85, 317-332

Li, J., Okin, G. S., Epstein, H. E., 2009. Effects of enhanced wind erosion on surface soil texture and characteristics of windblown sediments. J. Geophys. Res. Biogeosci., 114(G2).

Li, J., Okin, G. S., Tatarko, J., Webb, N. P., Herrick, J. E., 2014. Consistency of wind erosion assessments across land use and land cover types: A critical analysis. Aeolian Res. 15, 253260. 
828 LLUR - State Agency of Agriculture, Environment and Rural Areas of the Federal State

829 Schleswig-Holstein (Landesamt für Landwirtschaft, Umwelt und ländliche Räume des Landes

830 Schleswig-Holstein), 2010. Unpublished soil and management data of the long-term soil

831 monitoring system „Boden-Dauerbeobachtung“. Flintbek, Germany.

832

833 López, M.V., 1998. Wind erosion in agricultural soil: an example of limited supply of particles available for erosion. Catena 33, 17-28.

835

Louwagie, G. (Ed.), Schuler, J., Kutter, T., Zander, P., Funk, R., Helming, K., 2009. Addressing soil degradation in EU agriculture: relevant processes, practices and policies; report on the project "Sustainable Agriculture and Soil Conservation (SoCo)", 330 pp.; Luxembourg (European Communities, Office for Official Publications)

840

Lyles, L., Tatarko, J., 1987. Precipitation Effects on Ridges Created by Grain Drills. J. Soil Water Conserv. 42(4), 269-271.

843

Mendez, M. J., Funk, R., Buschiazzo, D. E., 2011. Field wind erosion measurements with Big

845 Spring Number Eight (BSNE) and Modified Wilson and Cook (MWAC) samplers.

846 Geomorphology 129, 1-2, 43-48

847

Nerger, R., Beylich, A., Fohrer, N., 2016. Long-term monitoring of soil quality changes in 849 Northern Germany. Geoderma Reg. 7(2), 239-249.

850

851

Öttl, D., Funk, R., 2007. PM emission factors for farming activities by means of dispersion 852 modeling, in: Hinz, T. and Tamoschkat-Depolt, K.: Particulate Matter in and from Agriculture. 853 FAL Agricultural Research, Special Issue 308, 173-177.

854

$855 \mathrm{Pi}$, H., Sharratt, B., Feng, G., Zhang, X., 2014. Comparison of measured and simulated 856 friction velocity and threshold friction velocity using SWEEP. Soil Sci., 179(8), 393-402.

857

858 Post W.M., Izaurralde R.C., Mann L.K., Bliss N., 2001. Monitoring and verifying changes of 859 organic carbon in soil. Clim. Change 51, 73-99.

860

861 Potter, K.N., 1990. Soil properties effect on random roughness decay by rainfall. Trans. 862 Amer. Soc. Agric. Engin. 33(6), 1889-1892. 
Prechtel, A., von Lützow, M., Uwe Schneider, B., Bens, O., Bannick, C. G., Kögel-Knabner, I., Hüttl, R. F., 2009. Organic carbon in soils of Germany: status quo and the need for new data to evaluate potentials and trends of soil carbon sequestration. J. Plant Nutr. Soil Sci. 172(5), 601-614.

Ramsperger, B., Peinemann, N., Stahr, K., 1998. Deposition rates and characteristics of aeolian dust in the semi-arid and sub-humid regions of the Argentinean Pampa. J. Arid. Environ. 39(3), 467-476.

Riksen, M., Brouwer, F., de Graaf, J., 2003. Soil conservation policy measures to control wind erosion in north-western Europe. Catena 52, 309-326.

Riksen, M., Brouwer, F., Spaan, W., Arrue, J.L., Lopez, M.V., 2003: What to do about wind erosion, in: Wind erosion on agricultural land in Europe. Ed. by Warren, A., European Commission, EUR 20370, 39-54.

Riksen, M. J. P. M., de Graaff, J., 2001. On-site and off-site effects of wind erosion on European light soils. Land Degrad. Dev., 12: 1-11. doi: 10.1002/ldr.423

Schäfer, W., Neemann, W. 1990. Bodenerosion durch Wind in Niedersachsen. Zeitschrift für Kulturtechnik und Landentwicklung 31, 72-81.

Schröder, W., Pesch, R., Schmidt, G., 2004. Soil monitoring in Germany. J. Soils Sediments $4(1), 49-58$.

Skidmore, E.L., Layton, J., 1992. Dry Soil Aggregate Stability as Influenced by Selected Soil Properties. Soil Sci. Soc. Am. J. 56, 557-561.

Springob, G., Brinkmann, S., Engel, N., Kirchmann, H., Böttcher, J., 2001. Organic carbon levels of Ap horizons in north German Pleistocene sands as influenced by climate, texture and history of land-use. J. Plant Nutr. Soil Sci. 164, 681-690.

Springob, G., Kirchmann, H., 2002. C-rich sandy Ap horizons of specific historical land-use contain large fractions of refractory organic matter. Soil Biol. Biochem. 34, 1571-1581. 
905

906

907

908

909

910

911

912

913

914

915

916

917

918

919

920

921

922

923

924

925

926

927

928

929

930

931

932

933

Springob, G., Kirchmann, $H_{\text {., }}$ 2003. Bulk soil $\mathrm{C}$ to $\mathrm{N}$ ratio as a simple measure of net $\mathrm{N}$ mineralization from stabilized soil organic matter in sandy arable soils. Soil Biol. Biochem. 35, 629-632.

Sterk, G., Herrmann, L., Bantiono, A., 1996. Wind-blown nutrient transport and soil productivity changes in southwest Niger. Land Degrad. Dev. 7, 325-335.

Traup, S., Kruse, B., 1996. Wind und Windenergiepotentiale in Deutschland. Winddaten für Windenergienutzer. Selbstverlag des Deutschen Wetterdienstes, Offenbach am Main, Germany. 445 pp.

Verheijen F.G.A., Jones R.J.A., Smith C.J., Rickson R.J., 2009. Tolerable versus actual soil erosion rates in Europe. Earth Sci. Rev. 94, 23-38.

Vigiak O., Sterk G., Warren A., Hagen L., 2003. Spatial modeling of wind speed around windbreaks. Catena 52, 273-288.

Wagner, L.E., Nelson, R.G., 1995. Mass reduction of standing and flat crop residues by selected tillage implements. Trans. Am. Soc. Agric. Eng. 38, 419-427.

Webb, N.P., Chappell, A., Strong, C.L., Marx, S.K., McTainsh, G.H., 2012. The significance of carbon-enriched dust for global carbon accounting. Glob. Change Biol. 18, 11, 3275-3278.

Webb, N. P., Herrick, J. E., Van Zee, J. W., Courtright, E. M., Hugenholtz, C. H., Zobeck, T. M., ... \& Clingan, S. D., 2016. The National Wind Erosion Research Network: Building a standardized long-term data resource for aeolian research, modeling and land management. Aeolian Res., 22, 23-36.

Zhang, J. Q., Zhang, C. L., Chang, C. P., Wang, R. D., Liu, G., 2017. Comparison of wind erosion based on measurements and SWEEP simulation: A case study in Kangbao County, Hebei Province, China. Soil Till Res., 165, 169-180.

Zobeck, T.M., 1991. Abrasion of crusted soils: influence of abrader flux and soil properties. Soil Sci. Soc. Am. J. 55, 1091-1097. 
934 Zobeck, T.M., Fryrear, D.W., 1986. Chemical and physical characteristics of windblown 935 sediment. II. Chemical characteristics and total soil and nutrient discharge. Trans. ASAE 29, 936 1037-1041.

937

938 Zobeck, T.M., Popham, T.W., 1992. Influence of microrelief, aggregate size and precipitation 939 on soil crust properties. Trans. Amer. Soc. of Agric. Engin. 35(2), 487-492.

940

941 